\title{
Serotonin modulation of cortical neurons and networks
}

\author{
Pau Celada ${ }^{1,2}$, M. Victoria Puig ${ }^{3}$ and Francesc Artigas ${ }^{1,2 *}$ \\ ' Department of Neurochemistry and Neuropharmacology, Institut d' Investigacions Biomèdiques de Barcelona (CSIC), IDIBAPS, Barcelona, Spain \\ ${ }^{2}$ Centro de Investigación Biomédica en Red de Salud Mental (CIBERSAM), Madrid, Spain \\ ${ }^{3}$ The Picower Institute for Learning and Memory, Massachusetts Institute of Technology, Cambridge, MA, USA
}

\section{Edited by:}

KongFatt Wong-Lin, University of Ulster, Northern Ireland

Reviewed by:

Rodrigo N. Romcy-Pereira,

Universidade Federal do Rio Grande do Norte, Brazil

Aaron Gruber, University of

Lethbridge, Canada

*Correspondence:

Francesc Artigas, Department of

Neurochemistry and

Neuropharmacology, Institut $d^{\prime}$ Investigacions Biomèdiques de Barcelona (CSIC), IDIBAPS, Rosselló 161, 6th floor, 08036 Barcelona, Spain.

e-mail: fapnqi@iibb.csic.es
The serotonergic pathways originating in the dorsal and median raphe nuclei (DR and $\mathrm{MnR}$, respectively) are critically involved in cortical function. Serotonin (5-HT), acting on postsynaptic and presynaptic receptors, is involved in cognition, mood, impulse control and motor functions by (1) modulating the activity of different neuronal types, and (2) varying the release of other neurotransmitters, such as glutamate, GABA, acetylcholine and dopamine. Also, 5-HT seems to play an important role in cortical development. Of all cortical regions, the frontal lobe is the area most enriched in serotonergic axons and 5-HT receptors. 5-HT and selective receptor agonists modulate the excitability of cortical neurons and their discharge rate through the activation of several receptor subtypes, of which the $5-\mathrm{HT}_{1 \mathrm{~A}}, 5-\mathrm{HT}_{1 \mathrm{~B}}, 5-\mathrm{HT}_{2 \mathrm{~A}}$, and $5-\mathrm{HT}_{3}$ subtypes play a major role. Little is known, however, on the role of other excitatory receptors moderately expressed in cortical areas, such as $5-\mathrm{HT}_{2} \mathrm{C}, 5-\mathrm{HT}_{4}, 5-\mathrm{HT}_{6}$, and $5-\mathrm{HT}_{7}$. In vitro and in vivo studies suggest that 5- $\mathrm{HT}_{1 \mathrm{~A}}$ and $5-\mathrm{HT}_{2 \mathrm{~A}}$ receptors are key players and exert opposite effects on the activity of pyramidal neurons in the medial prefrontal cortex (mPFC). The activation of $5-\mathrm{HT}_{1 \mathrm{~A}}$ receptors in mPFC hyperpolarizes pyramidal neurons whereas that of $5-\mathrm{HT}_{2 \mathrm{~A}}$ receptors results in neuronal depolarization, reduction of the afterhyperpolarization and increase of excitatory postsynaptic currents (EPSCs) and of discharge rate. 5-HT can also stimulate excitatory $\left(5-\mathrm{HT}_{2 \mathrm{~A}}\right.$ and $\left.5-\mathrm{HT}_{3}\right)$ and inhibitory $\left(5-\mathrm{HT}_{1 A}\right)$ receptors in GABA interneurons to modulate synaptic GABA inputs onto pyramidal neurons. Likewise, the pharmacological manipulation of various $5-\mathrm{HT}$ receptors alters oscillatory activity in PFC, suggesting that $5-\mathrm{HT}$ is also involved in the control of cortical network activity. A better understanding of the actions of 5-HT in PFC may help to develop treatments for mood and cognitive disorders associated with an abnormal function of the frontal lobe.

Keywords: 5-hydroxytryptamine or serotonin, dorsal raphe nucleus, electrophysiological recordings, GABAergic interneurons, oscillatory activity, prefrontal cortex, pyramidal neurons, serotonin receptors

\section{INTRODUCTION}

Serotonin (5-hydroxytryptamine, 5-HT) is one of the phylogenetically older molecules used in cellular communications. It is present in the central nervous system (CNS) of vertebrates and invertebrates and plays the role of neurotransmitter/neuromodulator. It also functions as a developmental signal in the CNS and regulates a variety of physiological functions in the periphery (where most 5 -HT is present), such as intestinal motility, platelet aggregation, and vasoconstriction.

Within the CNS, the serotonergic system is involved in a large number of functions resulting from its widespread innervation of the whole neuraxis. The axons of serotonergic neurons of the midbrain raphe nuclei reach almost every brain structure. Action potentials traveling along these axons release 5-HT which can act on pre- and postsynaptic receptors, coupled to different signal transduction mechanisms. So far, 14 different 5-HT receptor subtypes have been identified, corresponding to 7 different families: $5-\mathrm{HT}_{1}\left(5-\mathrm{HT}_{1 \mathrm{~A}}, 5-\mathrm{HT}_{1 \mathrm{~B}}, 5-\mathrm{HT}_{1 \mathrm{D}}, 5-\mathrm{HT}_{1 \mathrm{E}}\right.$, $\left.5-\mathrm{HT}_{1 \mathrm{~F}}\right), 5-\mathrm{HT}_{2}\left(5-\mathrm{HT}_{2 \mathrm{~A}}, 5-\mathrm{HT}_{2 \mathrm{~B}}, 5-\mathrm{HT}_{2} \mathrm{C}\right), 5-\mathrm{HT}_{3}, 5-\mathrm{HT}_{4}, 5-$ $\mathrm{HT}_{5}\left(5-\mathrm{HT}_{5 \mathrm{~A}}, 5-\mathrm{HT}_{5 \mathrm{~B}}\right), 5-\mathrm{HT}_{6}$, and $5-\mathrm{HT}_{7}$. With the exception of the $5-\mathrm{HT}_{3}$ receptor, a pentameric ligand-gated ion channel composed of several subunits (up to 5 different ones have been identified), the rest of 5-HT receptors belong to the superfamily of G-protein coupled receptors and their activation results mainly in modulatory actions in the neurons expressing these receptors.

Given the widespread innervation of the brain and the richness of signals evoked by 5-HT, it is not surprising that the 5-HT system is the target of many drugs used to treat brain diseases and also of recreational drugs. For instance, most antidepressant treatments block the 5-HT transporter and increase the extracellular (or synaptic) 5-HT concentration and hence, they indirectly elevate the serotonergic tone at pre- and postsynaptic 5-HT receptors. This action is supposed to mediate the therapeutic effect of these drugs. Moreover, some anxiolytic drugs are $5-\mathrm{HT}_{1 \mathrm{~A}}$ receptor agonists and $5-\mathrm{HT}_{3}$ receptor antagonists are commonly used to treat emesis induced by anti-cancer treatments.

On the other hand, drugs of abuse such as cocaine, amphetamine or MDMA (ecstasy) target monoaminergic transporters, including the 5-HT transporter. Furthermore hallucinogens like LSD, DOI, DOB, or DOM are $5-\mathrm{HT}_{2}$ receptor agonists whereas atypical antipsychotics act as preferential antagonists of 
these receptors [(Roth et al., 2004); see Geyer and Vollenweider (2008) for a review].

Among the various $5-\mathrm{HT}$ receptors, the $5-\mathrm{HT}_{1}$ family has probably received the largest attention because of the high density expression in limbic $\left(5-\mathrm{HT}_{1 \mathrm{~A}}\right)$ and motor $\left(5-\mathrm{HT}_{1 \mathrm{~B}}\right)$ brain areas and the various roles subserved by some of its members. Thus, in addition to being located postsynaptically to 5-HT axons, $5-\mathrm{HT}_{1 \mathrm{~A}}$ and $5-\mathrm{HT}_{1 \mathrm{~B}}$ receptors are autoreceptors in 5-HT neurons and therefore control the overall $\left(5-\mathrm{HT}_{1 \mathrm{~A}}\right)$ as well as the local (5- $\left.\mathrm{HT}_{1 \mathrm{~B}}\right)$ activity of the system. $5-\mathrm{HT}_{1 \mathrm{~B}}$ receptors are also terminal heteroreceptors and modulate the release of various transmitters, including dopamine, glutamate, GABA, and acetylcholine. Moreover, $5-\mathrm{HT}_{1 \mathrm{~A}}$ receptors are highly expressed by different neuronal types (mainly pyramidal but also GABAergic) in prefrontal cortex (PFC), which suggests an important role in the control of mood and emotions as well as in cognitive processes. An extensive review of the characteristics of the serotonergic system is beyond the scope of the present review. The reader is referred to several review papers dealing with the anatomy, physiology, neurochemistry, and neuropharmacology of the 5-HT system (Jacobs and Azmitia, 1992; Barnes and Sharp, 1999; Adell et al., 2002; Smythies, 2005; Artigas, 2013). In the following sections, we focus on the role of 5-HT in the modulation of cortical activity.

\section{THE CORTICAL 5-HT SYSTEM: RECEPTOR LOCALIZATION}

There is growing evidence that the serotonergic pathways originating in the dorsal and median paphe nuclei (DR and MnR, respectively) are critically involved in cortical functions. 5-HT appears to play an important role in the development of the somatosensory cortex and formation of the barrel cortex. In adult brain, the axons of 5-HT neurons innervate a large number of cortical areas, including the entorhinal and cingulate cortices, which contain a moderate to high density of 5-HT receptors. However, of all cortical regions, the frontal lobe is the richest area in serotonergic terminals and 5-HT receptors.

Yet, unlike dopamine, whose function in the PFC has been extensively studied (Williams and Goldman-Rakic, 1995; Robbins and Arnsten, 2009), the role of 5-HT in PFC remains less known than that of dopamine. Indeed, the widespread localization of 5HT receptors (particularly of the $5-\mathrm{HT}_{1 \mathrm{~A}}, 5-\mathrm{HT}_{2 \mathrm{~A}}$, and $5-\mathrm{HT}_{2 \mathrm{C}}$ subtypes) and the high density of 5 HT axons (greater than in any other cortical area) in this cortical region suggest an important role of 5-HT in cognitive and emotional functions depending on PFC activity. Hence, the selective depletion of 5-HT in the monkey frontal cortex impairs cognitive flexibility (increases perseveration), and reversal learning (Clarke et al., 2004, 2005), likely via 5- $\mathrm{HT}_{2 \mathrm{~A}}$ receptors (Carli et al., 2006; Boulougouris et al., 2007). In addition, optimized levels of 5-HT in the PFC are important for behavioral inhibition, as elevated or reduced 5-HT increases impulsivity (Harrison et al., 1997; Dalley et al., 2002; Winstanley et al., 2004). In fact, both stimulation of $5-\mathrm{HT}_{1 \mathrm{~A}}$ receptors and blockade of $5-\mathrm{HT}_{2 \mathrm{~A}}$ receptors decrease impulsivity (Winstanley et al., 2003; Carli et al., 2006; Talpos et al., 2006), suggesting that a downregulation of cortical serotonergic activity may effectively promote behavioral control. 5-HT in the frontal cortex is also involved in the modulation of attention in humans, an effect that implicates 5- $\mathrm{HT}_{1 \mathrm{~A}}$, but not 5- $\mathrm{HT}_{2 \mathrm{~A}}$, receptors (Carter et al., 2005; Scholes et al., 2006). Moreover, as observed for dopamine D1 receptors (Williams and Goldman-Rakic, 1995; Puig and Miller, 2012), the blockade of $5-\mathrm{HT}_{2 \mathrm{~A}}$ receptors in the monkey lateral PFC avoids the increase in neuronal activity during a working memory task (Williams et al., 2002), and a study associates allelic variants of this receptor with memory capacity in humans (De Quervain et al., 2003). Furthermore, hallucinogens like LSD or DOI are $5-\mathrm{HT}_{2 \mathrm{~A}}$ receptor agonists, which also suggests a role of 5-HT in the processing of external (sensory) and internal information through the activation of $5-\mathrm{HT}_{2 \mathrm{~A}}$ receptors. On the other hand, $5-\mathrm{HT}_{1 \mathrm{~A}}$ agonists display anxiolytic/antidepressant activity in animal models (Martin et al., 1990; De Vry, 1995; Carr and Lucki, 2011) whereas $5-\mathrm{HT}_{1 \mathrm{~A}}$ receptor antagonists reverse drug-induced cognitive deficits (Harder and Ridley, 2000; Mello e Souza et al., 2001; Misane and Ögren, 2003). Likewise, preclinical studies suggest that $5-\mathrm{HT}_{4}$ receptor agonists may exert rapid antidepressant actions by acting on PFC receptors (Lucas et al., 2007).

One of the key basic information relevant for the interpretation of physiological and behavioral data concerning the cortical 5-HT system is the regional and cellular localization of the 5-HT receptors. Several studies have examined the localization of 5-HT in the cortex. Early studies using receptor autoradiography and in situ hybridization enabled to identify the presence of various 5- $\mathrm{HT}$ receptors in cortical areas, notably the $5-\mathrm{HT}_{1 \mathrm{~A}}, 5-\mathrm{HT}_{2 \mathrm{~A}}$, and 5-HT $2 \mathrm{C}$ subtypes (Pazos and Palacios, 1985; Pazos et al., 1985; Pompeiano et al., 1992, 1994). Further studies identified the presence of other receptor subtypes, yet in lower density than these ones.

$5-\mathrm{HT}_{1 \mathrm{~A}}$ receptors are particularly enriched in the rodent medial PFC (mPFC), entorhinal cortex and, to a lesser extent, cingulate and retrosplenial cortices. Outside the cortex, they are densely expressed in the hippocampus, septum and the raphe nuclei. In the latter location, the receptor is almost exclusively expressed by 5-HT neurons, where it functions as an autoreceptor in the plasma membrane of perikarya and dendrites (Riad et al., 2000). PET scan studies using a radiolabeled selective antagonist $\left(\left[{ }^{11} \mathrm{C}\right]-\right.$ WAY-100635) have shown a very similar distribution in human brain, with an enrichment of the signal in the temporal and frontal lobes, cingulate cortex and the raphe nuclei (Martinez et al., 2001). Interestingly, as also observed in rats (Weber and Andrade, 2010), there is a marked rostro-caudal negative gradient in the abundance cortical of $5-\mathrm{HT}_{1 \mathrm{~A}}$ receptors, with the largest abundance in PFC.

Likewise, the neocortex of rodent, primate and human brains show a large abundance of $5-\mathrm{HT}_{2 \mathrm{~A}}$ receptors, with an enrichment in frontal regions (Pompeiano et al., 1994; Burnet et al., 1995; López-Giménez et al., 1998; Hall et al., 2000; Amargós-Bosch et al., 2004). Lower abundances are found in ventro-caudal part of CA3, medial mammillary nucleus, striatum (dorsal and ventral) and several brainstem nuclei (Pompeiano et al., 1994; Burnet et al., 1995; López-Giménez et al., 1998). Interestingly, pyramidal neurons in the rat PFC that simultaneously project to the ventral tegmental area and the dorsal raphe nucleus express $5-\mathrm{HT}_{2 \mathrm{~A}}$ receptors (Vázquez-Borsetti et al., 2009, 2011). This reveals a close anatomical interaction or "loop" between frontal areas and 
dopamine and serotonin neurons of the brainstem, as found in several electrophysiological studies (Thierry et al., 1979, 1983; Tong et al., 1996; Hajós et al., 1998; Celada et al., 2001; MartínRuiz et al., 2001). As for $5-\mathrm{HT}_{1 \mathrm{~A}}$ receptors, there is a good agreement between the autoradiographic and in situ hybridization signals, which indicates that the receptor is expressed mainly in the somatodendritic region. Similar regional distributions have been reported in human brain using the selective antagonist ligand M100907 in vivo (PET scan) or in vitro (autoradiography) (Hall et al., 2000).

$5-\mathrm{HT}_{1 \mathrm{~A}}$ and $5-\mathrm{HT}_{2 \mathrm{~A}}$ receptors are present in a high proportion of cells in some cortical regions. Double in situ hybridization studies, to label the cellular phenotype and the respective receptor mRNA, have shown that around $50 \%$ of pyramidal neurons (labeled with the vGluT1 mRNA) and 20-30\% of GABAergic interneurons (labeled with GAD65/67 mRNA) express 5- $\mathrm{HT}_{1 \mathrm{~A}}$ and/or $5-\mathrm{HT}_{2 \mathrm{~A}}$ receptor $\mathrm{mRNAs}$ in various areas of the $\mathrm{PFC}$ (Santana et al., 2004) (Table 1). Interestingly, about 30\% of parvalbumin-expressing fast-spiking interneurons in the $\mathrm{PFC}$ express $5-\mathrm{HT}_{1 \mathrm{~A}}$ or $5-\mathrm{HT}_{2 \mathrm{~A}}$ receptors which, unlike pyramidal neurons, are largely distributed in separate neuron populations (Puig et al., 2010).

Figure 1 shows the localization of the transcripts for $5-\mathrm{HT}_{1 \mathrm{~A}}$ and $5-\mathrm{HT}_{2 \mathrm{~A}}$ receptors in the $\mathrm{PFC}$ of the rat. Interestingly, 5$\mathrm{HT}_{1 \mathrm{~A}}$ and $5-\mathrm{HT}_{2 \mathrm{~A}}$ receptor transcripts are heavily co-expressed in rat and mouse PFC. Approximately $80 \%$ of the cells expressing $5-\mathrm{HT}_{1 \mathrm{~A}}$ receptor mRNA also express the $5-\mathrm{HT}_{2 \mathrm{~A}}$ receptor mRNA in all PFC areas examined, except in layer VI and the lower part of

Table 1 | Proportion of pyramidal and local GABAergic neurons that express the mRNAs encoding $5-\mathrm{HT}_{1 A}$ and $5-\mathrm{HT}_{2 A}$ receptors.

\begin{tabular}{|c|c|c|c|c|}
\hline & \multicolumn{2}{|c|}{ Pyramidal neurons } & \multicolumn{2}{|c|}{ GABAergic neurons } \\
\hline & $\begin{array}{l}5-\mathrm{HT}_{1 \mathrm{~A}} \\
\text { mRNA }\end{array}$ & $\begin{array}{l}5-\mathrm{HT}_{2 \mathrm{~A}} \\
\text { mRNA }\end{array}$ & $\begin{array}{l}5-\mathrm{HT}_{1 \mathrm{~A}} \\
\text { mRNA }\end{array}$ & $\begin{array}{l}5-\mathrm{HT}_{2 \mathrm{~A}} \\
\text { mRNA }\end{array}$ \\
\hline MOs & $54 \pm 4$ & $60 \pm 2$ & $28 \pm 6$ & $28 \pm 10$ \\
\hline ACAd & $54 \pm 3$ & $66 \pm 5$ & $22 \pm 4$ & $32 \pm 2$ \\
\hline $\operatorname{PrL}$ & $61 \pm 2$ & $51 \pm 3$ & $20 \pm 1$ & $34 \pm 1$ \\
\hline $\mathrm{ILA}^{a}$ & $40 \pm 4^{*}$ & $12 \pm 1^{* *}$ & $22 \pm 4$ & $22 \pm 3$ \\
\hline $\mathrm{TT}$ & $63 \pm 6$ & $81 \pm 3 * * *$ & $24 \pm 1$ & $24 \pm 2$ \\
\hline PIR & $60 \pm 2$ & $50 \pm 3$ & $21 \pm 6$ & $24 \pm 2$ \\
\hline Layer VI & $54 \pm 3$ & $26 \pm 3^{+}$ & $23 \pm 4$ & $11 \pm 3^{+}$ \\
\hline
\end{tabular}

Data are means of three rats and represent the percentage of the counted cells expressing the mRNAs of each 5-HT receptor in pyramidal (VGIUT1 mRNApositive) and GABAergic (GAD mRNA-positive) cells. MOs, secondary motor area; ACAd, dorsal anterior cingulate area; $\operatorname{PrL}$, prelimbic area; ILA, infralímbic area; PIR, piriform cortex; TT, tenia tecta. Layer Vla denotes deep areas of the sensorimotor cortex at prefrontal level.

a The data of the ILA correspond to its more ventral part, which shows a remarkable low level of 5-HT2A receptor, whereas cell counts from its dorsal part are more similar to those of $\mathrm{PrL}$.

${ }^{*} P<0.05$ vs. PrL, TT, and PIR; ${ }^{*} P<0.05$ vs. the rest of areas, except layer Vla $(P=0.9) ;{ }^{* *} P<0.05$ vs. the rest of areas; ${ }^{+} P<0.05$ vs. the rest of areas except ILA; ${ }^{++} P<0.05$ vs. ACAd and PrL (Tukey test post-ANOVA). Data from Santana et al. (2004). the infralimbic area, where the density of cells expressing $5-\mathrm{HT}_{2 \mathrm{~A}}$ receptors is much lower (Amargós-Bosch et al., 2004; Santana et al., 2004).

The abundant co-expression of $5-\mathrm{HT}_{1 \mathrm{~A}}$ and $5-\mathrm{HT}_{2 \mathrm{~A}}$ receptors raises questions about the physiological role of the simultaneous occurrence of inhibitory $\left(5-\mathrm{HT}_{1 \mathrm{~A}}\right)$ and excitatory $\left(5-\mathrm{HT}_{2 \mathrm{~A}}\right)$ receptors responding to $5-\mathrm{HT}$ in the same cortical neurons. Various hypotheses have been examined (Amargós-Bosch et al., 2004; Puig et al., 2005), but perhaps one of the most convincing explanations is the putative localization of both receptors in different cellular compartments. Thus, immunohistochemical studies by several groups-using different antibodies-consistently show a predominant location of $5-\mathrm{HT}_{2 \mathrm{~A}}$ receptors in the apical
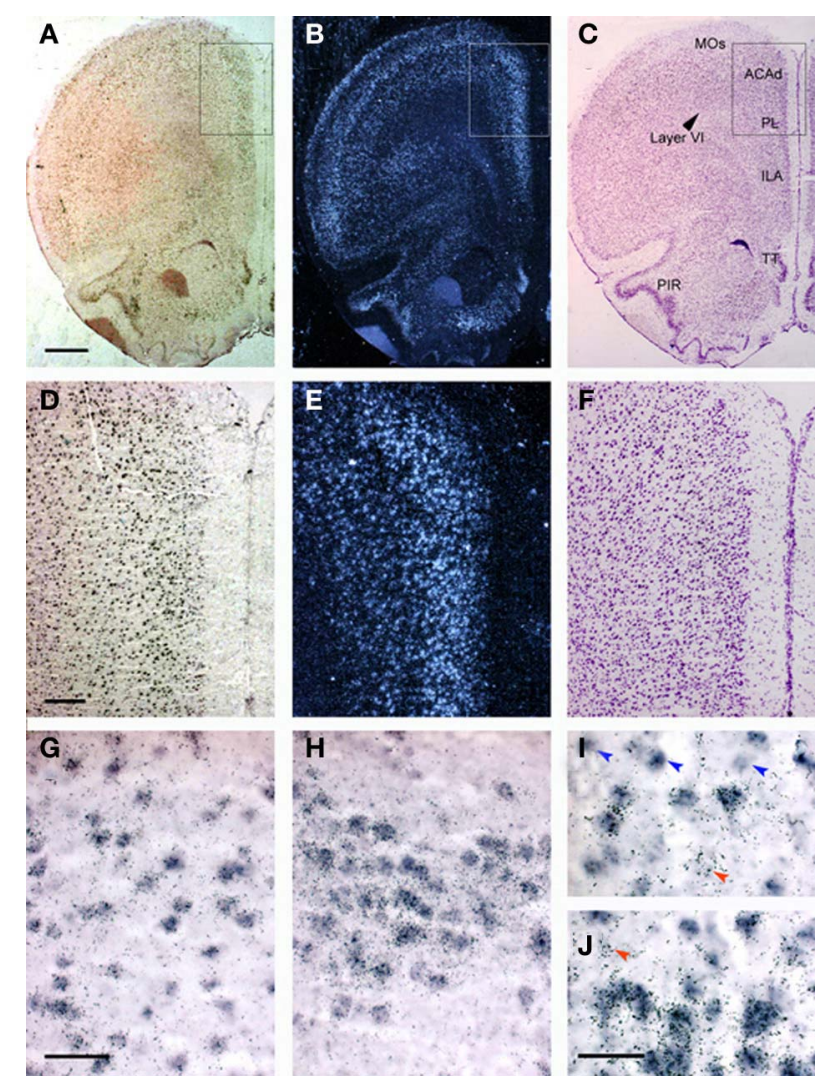

FIGURE 1 | Localization of $5-\mathrm{HT}_{1 \mathrm{~A}}$ and $5-\mathrm{HT}_{2 \mathrm{~A}}$ receptor mRNAs in the rat PFC using double in situ hybridization histochemistry. (A-C) Corona sections of rat PFC showing a large number of cells expressing (A) $5-\mathrm{HT}_{1} \mathrm{~A}$ receptors (Dig-labeled oligonucleotides) or (B) 5- $\mathrm{HT}_{2 \mathrm{~A}}$ receptors (dark field; 33P-labeled oligonucleotides); (C) an adjacent Nissl-stained section. Note the abundant presence of cells expressing both receptors in layers $\|-V$, as well as in piriform cortex (PIR) and tenia tecta (TT). (D-F) Enlargements of the marked area in panels $(\mathbf{A}-\mathbf{C})$. (D,E) Show the presence of a large number of cells containing $5-\mathrm{HT}_{1 \mathrm{~A}}$ and $5-\mathrm{HT}_{2 \mathrm{~A}}$ receptor transcripts in cingulate (ACAd) and prelimbic (PL) cortex. Cells in deep layers (VI) express preferentially $5-\mathrm{HT}_{1 \mathrm{~A}}$ receptor $\mathrm{mRNA}$. (G-J) Individual cells expressing both receptor transcripts. Occasional cell profiles containing only $5-\mathrm{HT}_{1 \mathrm{~A}}$ (blue arrowheads) or 5- $\mathrm{HT}_{2 \mathrm{~A}}$ receptor mRNAs (red arrowheads) were seen in the infralimbic cortex $(\mathbf{G}, \mathbf{I})$, piriform cortex $\mathbf{( H )}$ and taenia tecta $\mathbf{( J )}$. Bar size is $1 \mathrm{~mm}$ in (A-C), $250 \mu \mathrm{m}$ in (D-F), $50 \mu \mathrm{m}$ in $\mathbf{( G , H )}$ and $30 \mu \mathrm{m}$ in $\mathbf{( I , J ) . ~}$ Reproduced with permission from Amargós-Bosch et al. (2004). 
dendrites (and to a lower extent, cell bodies) of cortical pyramidal neurons (Jakab and Goldman-Rakic, 1998, 2000; Jansson et al., 2001; Martín-Ruiz et al., 2001), where they may amplify the impact of excitatory synaptic currents. On the other hand, there is a considerable disagreement in regards to the location of cortical $5-\mathrm{HT}_{1 \mathrm{~A}}$ receptors, due to the use of different antibodies. A homogenous labeling of cell bodies and dendrites was initially reported (Kia et al., 1996), but more recent studies performed in rodent, primate, and human brain tissues using a different antibody (Azmitia et al., 1996) show the exclusive labeling of the axon hillock of pyramidal neurons (De Felipe et al., 2001; Czyrak et al., 2003; Cruz et al., 2004). This location suggests that 5-HT axons would be able to establish axo-axonic contacts with pyramidal neurons, similar to those established by chandelier GABA interneurons, which would markedly impact on the generation of action potentials. In this way, 5-HT axons reaching apical dendrites would be able to modulate glutamatergic inputs onto pyramidal cells (Aghajanian and Marek, 1997; Puig et al., 2003) whereas those reaching axon hillocks would control the probability of generation of nerve impulses through the activation of $5-\mathrm{HT}_{1 \mathrm{~A}}$ receptors. However, existing discrepancies on the cellular localization of $5-\mathrm{HT}_{1 \mathrm{~A}}$ receptors prevent to draw firm conclusions on this point.

$5-\mathrm{HT}_{1 \mathrm{~B}}$ and $5-\mathrm{HT}_{1 \mathrm{D}}$ receptors show a widespread brain distribution, with a relative low abundance in cortex. Radioligand binding and autoradiographic studies have detected the presence of a high density of $5-\mathrm{HT}_{1 \mathrm{~B}}$ receptors in the basal ganglia and hippocampal formation, particularly the subiculum (Pazos and Palacios, 1985; Offord et al., 1988). They are negatively coupled to adenylate cyclase and activation of $5-\mathrm{HT}_{1 \mathrm{~B}}$ by selective agonists decreases the forskolin-stimulated adenylate cyclase levels [for review see Sari (2004)].

The comparison of autoradiographic, in situ hybridization and immunohistochemcial studies has revealed that $5-\mathrm{HT}_{1 \mathrm{~B}}$ receptors are located both presynaptically (i.e., on 5-HT axons) and postsynaptically to 5-HT neurons, mostly on axons of intrinsic neurons of the basal ganglia (Riad et al., 2000). Presynaptic 5-HT $1 \mathrm{~B}$ autoreceptors, however, represent a small proportion of the entire population of $5-\mathrm{HT}_{1 \mathrm{~B}}$ receptors in the brain because the lesion of 5-HT neurons does not generally result in a reduction of their density (Compan et al., 1998). Notwithstanding the low density of cortical $5-\mathrm{HT}_{1 \mathrm{~B}}$ receptors seen by autoradiography, electrophysiological studies have identified $5-\mathrm{HT}_{1 \mathrm{~B}}$ receptor-mediated actions in the cingulate cortex of the rat (Tanaka and North, 1993; see below). The other two members of the $5-\mathrm{HT}_{1}$ family $\left(5-\mathrm{HT}_{1 \mathrm{E}}\right.$ and $5-\mathrm{HT}_{1 \mathrm{~F}}$ receptors) are also present in cortex, particularly entorhinal cortex, yet their low abundance and the lack of selective pharmacological tools have hampered the study of their actions on cortical neurons.

$5-\mathrm{HT}_{2 \mathrm{~B}}$ receptors are expressed in a very low density in the brain. In contrast, $5-\mathrm{HT}_{2} \mathrm{C}$ receptors (formerly named $5-\mathrm{HT}_{1 \mathrm{C}}$ receptors) are highly expressed in the choroid plexus (where they were initially identified), various cortical areas in the rodent brain, particularly the PFC, the limbic system (nucleus accumbens, hippocampus, amygdala) and the basal ganglia (caudate nucleus, substantia nigra). $5-\mathrm{HT}_{2 \mathrm{C}}$ receptors are also expressed in the human cortex, yet their abundance relative to other brain areas appears to be lower than in rat brain (Clemett et al., 2000; Pandey et al., 2006). Interestingly, immunohistochemical studies suggest that cortical $5-\mathrm{HT}_{2} \mathrm{C}$ receptors are mainly expressed in pyramidal neurons (Clemett et al., 2000; Puig et al., 2010), and not in fast-spiking interneurons (Puig et al., 2010), yet data using a different antibody indicate that more than $50 \%$ of the $5-\mathrm{HT}_{2} \mathrm{C}$ receptor immunoreactivity is present in GABAergic neurons (Liu et al., 2007).

$5-\mathrm{HT}_{3}$ receptors are moderately abundant in the neocortex and other telecephalic regions, such as the olfactory cortex, the hippocampus, and the amygdala. Interestingly, most cortical 5$\mathrm{HT}_{3}$ receptor mRNA is located in GABAergic interneurons, as assessed by in situ hybridization (Morales and Bloom, 1997; Puig et al., 2004). These are calbindin- and calretinin-(but not parvalbumin-) containing neurons and are located in superficial cortical layers (I-III) (Morales and Bloom, 1997; Puig et al., 2004)

(Figure 2).

$5-\mathrm{HT}_{4}$ receptors are abundant in the olfactory tubercle, some structures of the basal ganglia (caudate putamen, ventral
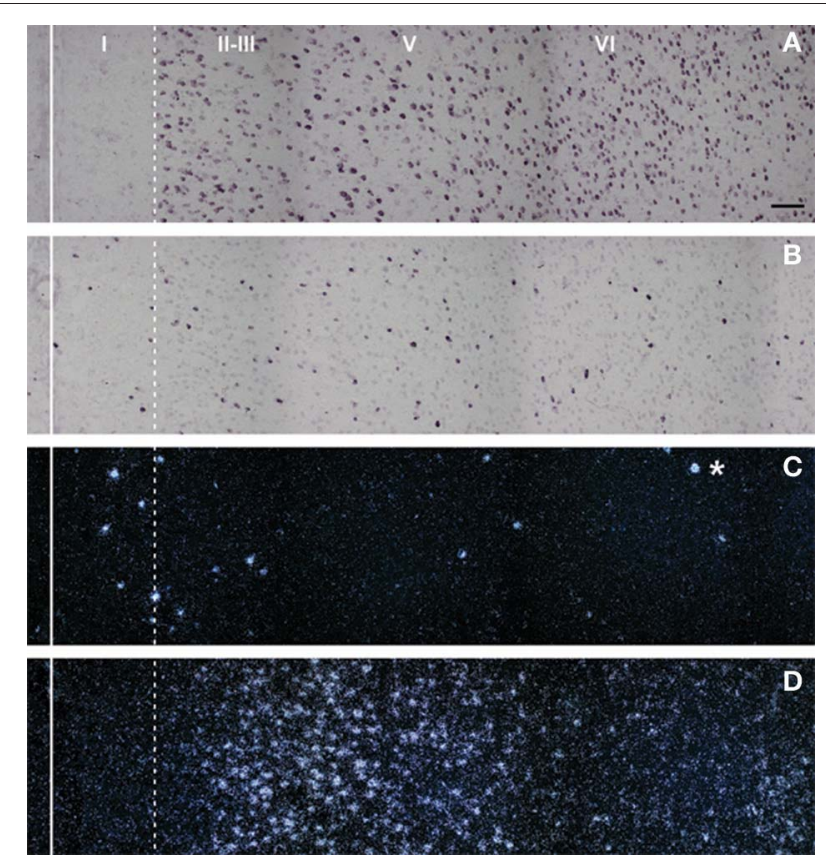

FIGURE 2 | Composite photomicrographs showing the localization of cells expressing vGluT1 (A), GAD (B), 5- $\mathrm{HT}_{3}$ (C), and 5- $\mathrm{HT}_{2 A}$ (D) mRNAs through layers $\mathrm{I}-\mathrm{VI}$ at the level of the prelimbic area in the rat PFC. The continuous vertical line denotes the location of the midline whereas the dotted line shows the approximate border between layer I and II. Pyramidal neurons (as visualized by vGluT1 mRNA) are present in layers II-VI whereas GAD mRNA-positive cells are present in all layers, including layer I. Note the segregation of cells expressing $5-\mathrm{HT}_{3}$ (C) and 5- $\mathrm{HT}_{2 \mathrm{~A}}$ receptors (D). $5-\mathrm{HT}_{3}$ receptor transcript is expressed by a limited number of cells present in layers I-III, particularly in the border between layers I and II. However, they represent $40 \%$ of GABAergic neurons in layer I. On the other hand, cells in these locations, particularly in layer I, do not express $5-\mathrm{HT}_{2 \mathrm{~A}}$ receptors. The asterisk denotes an artifact of the emulsion, seen in the dark field. Scale bar $=150 \mu \mathrm{m}$. Reproduced with permission from Puig et al. (2004). 
striatum), medial habenula, hippocampal formation, and amygdala. The neocortex contains low levels of the $5-\mathrm{HT}_{4}$ receptor and its encoding mRNA, as assessed by autoradiography and in situ hybridization, respectively (Waeber et al., 1994; Vilaró et al., 1996, 2005). However, studies using single-cell RT-PCR technique reported that $\sim 60 \%$ of pyramidal neurons recorded in the PFC contain the $5-\mathrm{HT}_{4}$ receptor transcript (Feng et al., 2001), and overexpression of 5- $\mathrm{HT}_{4}$ in the mPFC increases DRN 5-HT activity (Lucas et al., 2005) likely through descending excitatory axons reaching the DR (Celada et al., 2001; Vázquez-Borsetti et al., 2011).

$5-\mathrm{HT}_{5}$ receptors are the less well understood 5-HT receptors. Both $5-\mathrm{HT}_{5 \mathrm{~A}}$ and $5-\mathrm{HT}_{5 \mathrm{~B}}$ receptor subtypes were found in rodents whereas only the $5-\mathrm{HT}_{5 \mathrm{~A}}$ was identified in human brain. The $5-\mathrm{HT}_{5 \mathrm{~A}}$ receptor $\mathrm{mRNA}$ is found in relative high levels in the hippocampus, the medial habenula and the raphe but is absent in cortex. The occurrence of the receptor in the midbrain raphe, where the cell bodies of 5-HT neurons are located raises the possibility that it may directly or indirectly influence the activity of 5-HT neurons, and thus the levels of 5-HT in the target structures. On the other hand, the $5-\mathrm{HT}_{5 \mathrm{~B}}$ receptor mRNA is present throughout the rat brain, with higher levels in the hippocampus, hypothalamus, pons, and cortex (Erlander et al., 1993).

The richest brain areas in $5-\mathrm{HT}_{6}$ receptor mRNA are the ventral striatum and adjacent areas (nucleus accumbens, olfactory tubercle, islands of Calleja) as well as the dorsal striatum (caudate-putamen). High levels of $5-\mathrm{HT}_{6}$ receptor mRNA are also found in the hypothalamus and the hippocampus, whereas the cerebral cortex, the substantia nigra, and the spinal cord contain low/moderate levels of the transcript (Gerard et al., 1996). Immunohistochemical studies have confirmed a similar distribution of the receptor protein, although the PFC shows a labeling density greater than that of the mRNA and similar to that of the hippocampus (Gerard et al., 1997).

Finally, the $5-\mathrm{HT}_{7}$ receptor mRNA is localized to discrete regions of the rodent brain. Higher levels are present in the thalamus and the hippocampus whereas moderate levels are seen in the septum, the hypothalamus, the centromedial amygdala, and the periaqueductal gray. Autoradiographic studies indicate the presence of a similar distribution of the binding sites, in the cortex, septum, thalamus, hypothalamus, centromedial amygdala, periaqueductal gray, and superior colliculus (Gustafson et al., 1996). A similar distribution of $5-\mathrm{HT}_{7}$ receptor was reported in human brain (Martin-Cora and Pazos, 2004). Interestingly, the $5-\mathrm{HT}_{7}$ receptor is also localized in the raphe nuclei in both rodent and human brain, which has raised interest of targeting 5-HT receptors as a potential new mechanism to control brain's 5-HT levels by regulating the neuronal activity of the ascending 5-HT systems.

In summary, 5-HT released from axons innervating the cerebral cortex can modulate the activity of cortical neurons through several distinct receptors. However, with few exceptions (see above) little is known about the cellular phenotype of the neurons expressing 5-HT receptors, their precise distribution in cortical layers and the proportion of neurons of each type (e.g., pyramidal, stellate, or GABAergic neurons) expressing the receptor subtypes. The knowledge of these data is deemed important to identify the cellular elements and local circuitry involved in the cortical actions of 5-HT.

\section{ROLE OF 5-HT RECEPTORS ON CORTICAL NEURON ACTIVITY 5-HT 1 A RECEPTORS}

The $5-\mathrm{HT}_{1 \mathrm{~A}}$ receptor has been characterized biochemically and electrophisiologically as being coupled to the Gi/o family of heterotrimeric $\mathrm{G}$ proteins. $\mathrm{Gi} / \mathrm{o}$ proteins coupled to $5-\mathrm{HT}_{1 \mathrm{~A}}$ receptors are composed of pertussis toxin sensitive $\alpha \mathrm{i} / \alpha$ o subunits. This coupling mechanism was demonstrated in vivo and in vitro in the DR (Innis and Aghajanian, 1987). In hippocampal cells (as well as in 5 -HT cells) a similar $\mathrm{G}$ protein couples $5-\mathrm{HT}_{1 \mathrm{~A}}$ and $\mathrm{GABA}_{\mathrm{B}}$ receptors to potassium channels (Andrade et al., 1986).

$5-\mathrm{HT}_{1 \mathrm{~A}}$ receptors are also coupled to potassium and-to a lesser extent-calcium channels. Intracellular current-clamp recordings in slices containing the DR had indicated that the 5-HT-mediated inhibition is mediated by an enhancement of the inward rectifying potassium conductance (Aghajanian and Lakoski, 1984; Williams et al., 1988). Exogenous application of 5-HT and 5- $\mathrm{HT}_{1 \mathrm{~A}}$ agonists also elicit membrane potential hyperpolarization and decreased the membrane input resistance in DR 5-HT neurons in vitro (Aghajanian and Lakoski, 1984; Sprouse and Aghajanian, 1987), leading to an overall reduction in the probability of action potential firing. Similar effects to $5-\mathrm{HT}_{1 \mathrm{~A}}$ receptor activation have been reported in other neuronal types, such as hippocampal pyramidal cells (Andrade and Nicoll, 1987). $5-\mathrm{HT}_{1 \mathrm{~A}}$ receptors are also involved in the modulation of excitatory glutamatergic neurotransmission, since their activation suppresses AMPA-mediated signaling through the inhibition of CAMKII (Cai et al., 2002a) and reduces NMDA-mediated currents in PFC neurons (Zhong et al., 2008).

Early in vivo electrophysiological recordings showed that iontophoretic application of 5-HT excited and inhibited different cortical neurons (Krnjevic and Phillis, 1963; Roberts and Straughan, 1967), even though the major effect of 5-HT was inhibition of firing (Krnjevic and Phillis, 1963; Reader et al., 1979; Ashby et al., 1994; Zhang et al., 1994). Studies in the neocortex showed that 5-HT application also induced a hyperpolarization followed by a depolarization in a subpopulation of neurons (Davies et al., 1987; Tanaka and North, 1993). These effects were mediated, respectively by an action of 5-HT on 5$\mathrm{HT}_{1 \mathrm{~A}}$ and 5-HT 2 receptors (Araneda and Andrade, 1991), and can be likely accounted for by the high co-expression of $5-\mathrm{HT}_{1 \mathrm{~A}}$ and $5-\mathrm{HT}_{2 \mathrm{~A}}$ receptors in cortical neurons (Amargós-Bosch et al., 2004). The three major actions of 5-HT on the activity of cortical neurons (inhibitions, excitations, and biphasic responses) have been recently found in layer $\mathrm{V}$ pyramidal neurons of mice PFC slices to be mediated by $5-\mathrm{HT}_{1 \mathrm{~A}}$ and $5-\mathrm{HT}_{2 \mathrm{~A}}$ receptors (Avesar and Gulledge, 2012) (Figure 3). Similarly, both hyperpolarizing $\left(5-\mathrm{HT}_{1 \mathrm{~A}}\right.$ receptor-mediated) and depolarizing $\left(5-\mathrm{HT}_{2 \mathrm{~A}}\right.$ receptormediated) responses to 5-HT have been demonstrated in human neocortex in vitro (Newberry et al., 1999).

In entorhinal cortex neurons recorded in the current clamp mode, 5-HT evoked a biphasic response consisting of a large amplitude hyperpolarization followed by a slowly developing, long lasting, and small amplitude depolarization. In voltage clamp, 5-HT consistently evoked an outward current by a smaller 


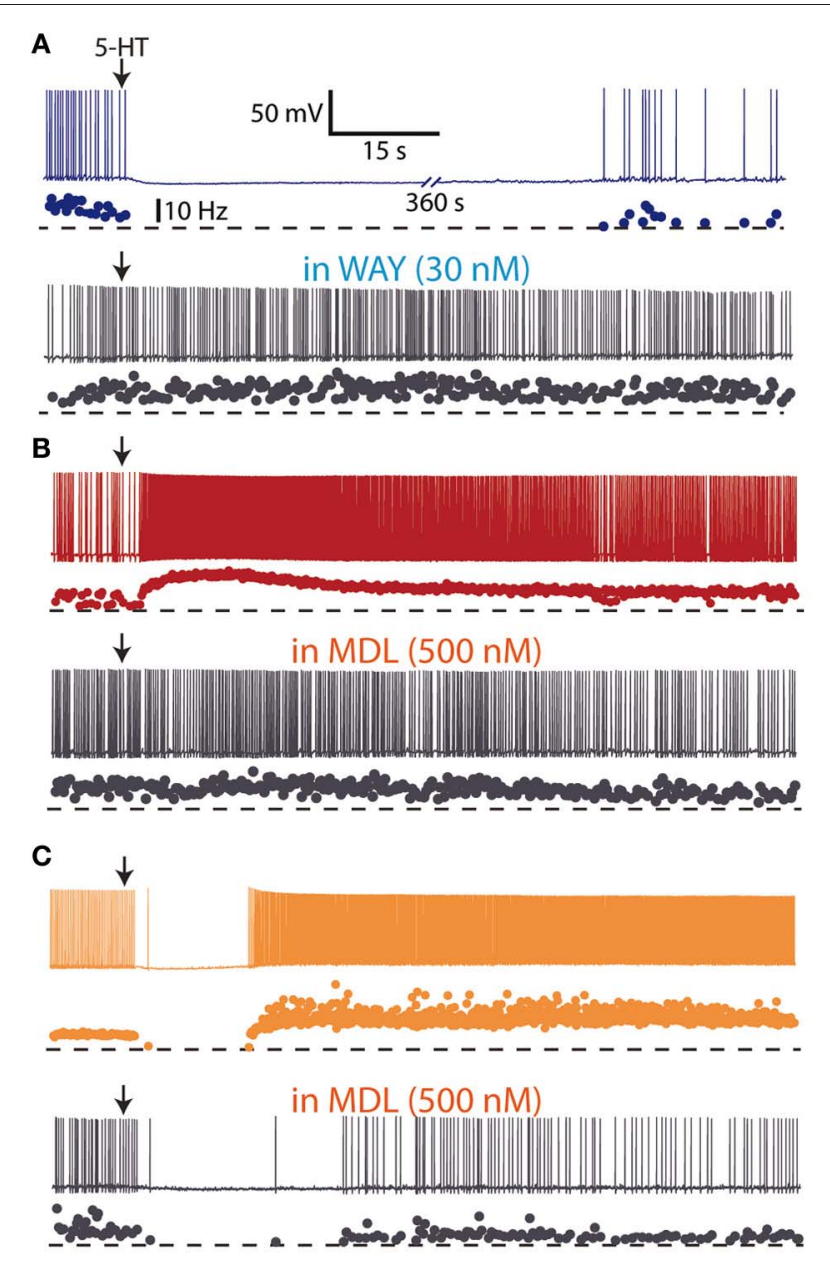

FIGURE 3 | Hyperpolarizing and depolarizing effects of 5-HT in layer V pyramidal neurons of medial prefrontal cortex slices from mice. (A) Focal (local) application of 5-HT $(100 \mu \mathrm{M})$ elicited a hyperpolarizing response which was blocked by the $5-\mathrm{HT}_{1 \mathrm{~A}}$ antagonist WAY 100635 (30 nM), suggesting the expression of $5-\mathrm{HT}_{1 \mathrm{~A}}$ receptors. (B) Focal application of $5-H T(100 \mu \mathrm{M})$ elicited a depolarizing response which was blocked by the $5-\mathrm{HT}_{2 \mathrm{~A}}$ antagonist MDL $11939(500 \mathrm{nM})$, suggesting the expression of $5-\mathrm{HT}_{2 \mathrm{~A}}$ receptors. (C) Focal application of $5-\mathrm{HT}(100 \mu \mathrm{M})$ elicited a biphasic response sensitive to the $5-\mathrm{HT}_{2 \mathrm{~A}}$ antagonist MDL 11939 (500 nM). Redrawn from Avesar and Gulledge (2012) with permission from A. Gulledge.

inward shift of holding current. The outward current was mediated by the activation of 5- $\mathrm{HT}_{1 \mathrm{~A}}$ receptors (Ma et al., 2007).

Systemic administration of selective $5-\mathrm{HT}_{1 \mathrm{~A}}$ receptor agonists suppresses the firing activity of 5-HT neurons in the DR and MnR (Blier and de Montigny, 1987; Hajós et al., 1995; Casanovas et al., 2000) and hippocampal neurons (Tada et al., 1999). However, these agents appear to have a more complex effect on cortical (PFC) pyramidal neurons, with either a biphasic effect (increase in firing activity at lower doses followed by decrease at higher doses) or affecting different neuronal populations in a distinct manner (most neurons excited by $5-\mathrm{HT}_{1 \mathrm{~A}}$ agonists) (Borsini et al., 1995; Hajos et al., 1999; Diaz-Mataix et al., 2006; LladóPelfort et al., 2010, 2012a,b). Thus, the systemic administration of the selective $5-\mathrm{HT}_{1 \mathrm{~A}}$ receptor agonist $8-\mathrm{OH}-\mathrm{DPAT}$ increased the firing activity of pyramidal neurons and reduced that of fastspiking GABAergic interneurons, suggesting a preferential action of $5-\mathrm{HT}_{1 \mathrm{~A}}$ agonists on $5-\mathrm{HT}_{1 \mathrm{~A}}$ receptors in fast-spiking GABA interneurons, particularly at lower doses (Lladó-Pelfort et al., 2012b).

\section{5-HT $1 \mathrm{~B} /$ 1D RECEPTORS}

Anatomical and pharmacological evidence indicate that $5-\mathrm{HT}_{1 \mathrm{~B}}$ receptors have an axonal localization in different cerebral pathways and it exerts an inhibitory action on neurotransmitter release (Sari, 2004). Furthermore, electrophysiological evidence of the role of $5-\mathrm{HT}_{1 \mathrm{~B}}$ receptors in neuronal function is based on the assessment of inhibitory actions on evoked synaptic potentials or currents in target neurons whereas neurochemical studies have examined direct effects on neurotransmitter release.

The control of glutamate release by $5-\mathrm{HT}_{1 \mathrm{~B}}$ receptors has been described in different brain areas. In slices of cingulate cortex, 5-HT, acting on 5- $\mathrm{HT}_{1 \mathrm{~B}}$ receptors, reduced the amplitude of NMDA and non-NMDA components of synaptic potentials recorded intracellularly in layer $\mathrm{V}$ pyramidal neurons (Tanaka and North, 1993) (Figure 4). It has been also reported that 5- $\mathrm{HT}_{1 \mathrm{~B}}$ receptors mediate the 5-HT suppression of evoked fast excitatory postsynaptic current (evEPSC) in layer V pyramidal neurons in response to nearby electrical stimulation of cortical afferents (Lambe and Aghajanian, 2004).

\section{5-HT2A/2C RECEPTORS}

$5-\mathrm{HT}_{2 \mathrm{~A}}$ receptors are coupled to phospholipases through $\mathrm{Gq}$ proteins. Their activation entrains the production of IP3, diacylglycerol and the mobilization of intracellular $\mathrm{Ca}^{2+}$ stores. Furthermore, it is widely recognized that it is the main G-proteincoupled receptor through which 5-HT has excitatory actions. However, some aspects are highly controversial, including the localization of receptors responsible for the actions of 5-HT and $5-\mathrm{HT}_{2 \mathrm{~A}}$ agonists.

There is a substantial overlap between the localization of 5-HT axon terminals and $5-\mathrm{HT}_{2}$ receptors in rat cortex (Blue et al., 1988). 5- $\mathrm{HT}_{2 \mathrm{~A}}$ receptors are localized both to pyramidal neurons and GABAergic interneurons in the PFC (Willins et al., 1997; Jakab and Goldman-Rakic, 1998; Santana et al., 2004). 5$\mathrm{HT}_{2 \mathrm{~A}}$ receptors are highly expressed in large and medium-size parvalbumin- and calbindin-containing interneurons involved in the feed-forward inhibition of pyramidal neurons (Jakab and Goldman-Rakic, 2000; Puig et al., 2010). In the rat frontoparietal cortex, 5-HT axons are parallel to the apical dendrites of pyramidal neurons expressing 5- $\mathrm{HT}_{2 \mathrm{~A}}$ receptors (Jansson et al., 2001). Additionally, a lower proportion of $5-\mathrm{HT}_{2 \mathrm{~A}}$ receptors was found presynaptically (Jakab and Goldman-Rakic, 1998; Miner et al., 2003).

Activation of $5-\mathrm{HT}_{2 \mathrm{~A}}$ receptors exerts complex effects on the activity of PFC neurons. Thus, the microiontophoretic application of DOI suppressed the firing activity of putative pyramidal neurons in anesthetized rats but enhanced the excitatory effect of glutamate at low ejection currents (Ashby et al., 1990). In vitro recordings of identified pyramidal neurons in PFC slices have revealed that $5-\mathrm{HT}_{2 \mathrm{~A}}$ receptor activation increases spontaneous EPSCs and depolarizes the recorded cells (Araneda and Andrade, 

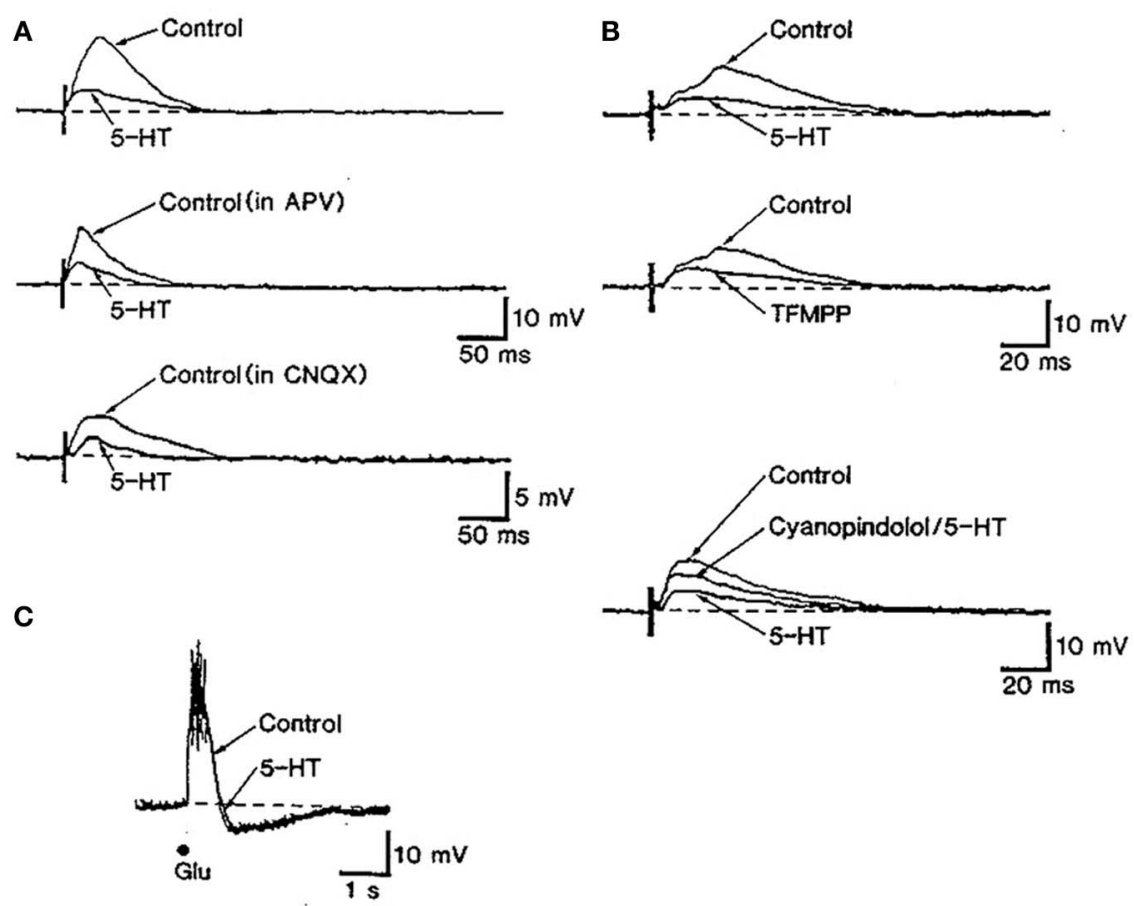

FIGURE 4 | The stimulation of $5-\mathrm{HT}_{1 \mathrm{~B}}$ receptors inhibits excitatory synaptic transmission in rat cingulate cortex. (A) The stimulation of subcortical white matter elicited excitatory postsynaptic synaptic potentials (EPSP) dependent on NMDA and non-NMDA currents in in cingulate cortex pyramidal neurons. The action of 5-HT partially depressed EPSPS. (B) The reduction of EPSPS by 5-HT was mimicked by the non-selective $5-\mathrm{HT}_{1 \mathrm{~B}}$ agonist TFMPP and was antagonized by the $5-\mathrm{HT}_{1 \mathrm{~B}}$ antagonist cyanopindolol. (C) The depressing action of serotonin appears to be mediated by a presynaptic action of 5-HT since the depolarizing effect of glutamate was unaffected by 5-HT application. Reproduced with permission from Tanaka and North (1993).
1991; Tanaka and North, 1993; Aghajanian and Marek, 1997, 1999a,b; Zhou and Hablitz, 1999; Avesar and Gulledge, 2012) (Figures 3, 5). In addition, 5-HT can elicit 5- $\mathrm{HT}_{2 \mathrm{~A}}$-mediated IPSCs through the activation of GABA synaptic inputs (Zhou and Hablitz, 1999), an effect that can be accounted for by the activation of $5-\mathrm{HT}_{2 \mathrm{~A}}$ receptors in GABAergic interneurons (Santana et al., 2004).

Importantly, recent studies have provided new insights into the role of $5-\mathrm{HT}_{2 \mathrm{~A}}$-mediated excitations and $5-\mathrm{HT}_{1 \mathrm{~A}}$-mediated inhibitions in PFC circuits. 5-HT generated 5- $\mathrm{HT}_{2 \mathrm{~A}}$-mediated excitatory or biphasic responses in all callosal/commissural (COM) neurons responsive to 5-HT in vitro, whereas corticopontineprojecting neurons $(\mathrm{CPn})$ were universally inhibited by 5$\mathrm{HT}$ through 5- $\mathrm{HT}_{1 \mathrm{~A}}$ receptors (Avesar and Gulledge, 2012). Additionally, cortico-mesencephalic pyramidal neurons respond to $5-\mathrm{HT}_{1 \mathrm{~A}}$ and/or $5-\mathrm{HT}_{2 \mathrm{~A}}$ receptor activation, as indicated by in vivo physiological (Puig et al., 2005) and pharmacological studies (Celada et al., 2001; Martín-Ruiz et al., 2001; Bortolozzi et al., 2005). Thus, 5-HT may exert different and projection-selective actions on PFC pyramidal neurons, activating cortico-cortical output channels, having mixed actions on some cortico-subcortical output channels and inhibiting other cortical pyramidal neurons, particularly CPn neurons. $5-\mathrm{HT}_{2 \mathrm{~A}}$ receptor-dependent serotonergic excitation of COM neurons may also be related to the parallel rostral-to-caudal gradients found for cortical 5- $\mathrm{HT}_{2 \mathrm{~A}}$ receptors expression (Pazos et al., 1985; Weber and Andrade, 2010) and COM neuron density (Chao et al., 2009).

One of the most important mechanisms by which $5 \mathrm{HT}$ increases pyramidal cell excitability seems to be mediated by the inhibition of the afterhyperpolarizating current (IAHP) typically observed after a burst of spikes in response to $5-\mathrm{HT}_{2}$ receptor activation (Araneda and Andrade, 1991; Andrade, 1998). Accordingly, studies conducted in layer V neurons of PFC have identified $5-\mathrm{HT}_{2 \mathrm{~A}}$ receptors as the primarily receptor involved in the inhibitory effect of 5-HT on the slow afterhyperpolarizating current (IsAHP), suggesting also the contribution of additional 5-HT receptor subtypes (Villalobos et al., 2005). As AHP is involved in determining neuronal excitability, such an inhibition could contribute to regulate firing pattern activity of cortical neurons. Interestingly, the $5-\mathrm{HT}_{2 \mathrm{~A} / 2 \mathrm{C}}$ receptor agonist DOI markedly affects the firing activity of PFC pyramidal neurons in vivo (Puig et al., 2003). Systemic DOI administration increased, decreased or left unaffected the activity of pyramidal neurons in PFC by a 5- $\mathrm{HT}_{2 \mathrm{~A}}$ receptor-dependent mechanism. As observed for 5-HT (Zhou and Hablitz, 1999), inhibitory actions of DOI seems to be dependent on $\mathrm{GABA}_{\mathrm{A}}$ receptor tone, suggesting the involvement of $5-\mathrm{HT}_{2 \mathrm{~A}}$ receptors in GABAergic interneurons.

There seems to be a tight link between $5-\mathrm{HT}_{2 \mathrm{~A}}$ receptors and glutamatergic transmission. Hence, the excitatory effects of DOI appear to involve interaction with glutamatergic transmission 


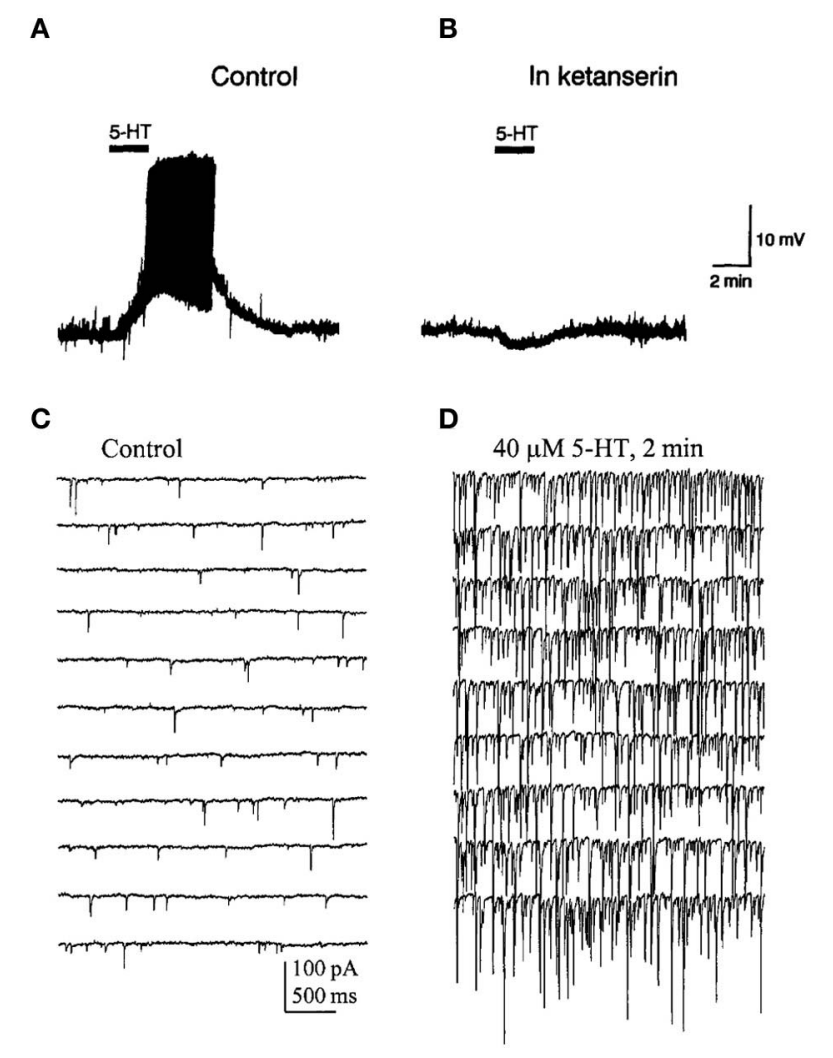

FIGURE 5 | (A) Bath application of 5-HT evoked a depolarization and induced firing in a pyramidal neuron of the PFC. (B) Effect of ketanserin (5- $\mathrm{HT}_{2 \mathrm{~A} / 2 \mathrm{C}}$ receptor antagonist) on the 5 - $\mathrm{HT}$-induced membrane depolarization. Notice that in the presence of ketanserin $5-\mathrm{HT}$ elicited a small hyperpolarization. (C,D) Spontaneous IPSCs recorded in a PFC pyramidal neuron in presence of AP-V and CNOX to block glutamatergic inputs. (D) IPSCs evoked by the bath application of 5-HT in the same recording conditions. Note the large increase in the frequency and amplitude of IPSCs induced by 5-HT. Reproduced with permission from Araneda and Andrade (1991) (panels A,B) and Zhou and Hablitz (1999) (panels C,D).

because DOI increases the excitatory effects of glutamate on prefrontal neurons (Ashby et al., 1989a, 1990). Likewise, the 5- $\mathrm{HT}_{2 \mathrm{~A}}$ receptor-mediated EPSCs evoked by $5-\mathrm{HT}$ in $\mathrm{mPFC}$ slices are occluded by blockade of AMPA receptors and mGluR II receptor activation (Aghajanian and Marek, 1997, 1999a,b). Moreover, the modulation of prefrontal NMDA transmission by $5-\mathrm{HT}$ and $\mathrm{DOB}$ appears to involve pre- and postsynaptic $5-\mathrm{HT}_{2 \mathrm{~A}}$ receptors (Arvanov et al., 1999). Likewise, 5-HT modulates NMDA transmission in $\mathrm{PFC}$ via $5-\mathrm{HT}_{1 \mathrm{~A}}$ and $5-\mathrm{HT}_{2 \mathrm{~A}}$ receptors, with opposite actions of both receptors (Yuen et al., 2008; Zhong et al., 2008). Finally, the observation that the selective mGluRII agonist LY-379268 reversed the excitatory effect of DOI on pyramidal neurons in vivo is consistent with these in vitro observations (Puig et al., 2003).

It has been suggested that in mPFC 5-HT activates $5-\mathrm{HT}_{2 \mathrm{~A}}$ receptors located putatively on thalamocortical terminals to release glutamate and evoke EPSCs in pyramidal cells (Aghajanian and Marek, 1997). This interpretation was based on a number of observations, including the fact that this effect was antagonized by AMPA receptor antagonists and mGluR agonists (Aghajanian and Marek, 1997, 1999a,b). Similarly, the increase in pyramidal cell firing evoked by systemic DOI administration was dependent on glutamate inputs (Puig et al., 2003). However, the lesion of the thalamus (including the dorsomedial and centromedial nuclei which project to mPFC) (Berendse and Groenewegen, 1991; Fuster, 1997) did not abolish the excitatory effects of DOI on mPFC pyramidal neurons (Puig et al., 2003). Likewise, in vitro electrophysiological studies in $5-\mathrm{HT}_{2 \mathrm{~A}}$ receptor knockout mice are also discordant with the existence of presynaptic 5$\mathrm{HT}_{2 \mathrm{~A}}$ receptors in thalamocortical afferents (Béique et al., 2007) and electron microscopy studies have failed to identify $5-\mathrm{HT}_{2 \mathrm{~A}}$ receptors in excitatory axonal terminals in the $\mathrm{mPFC}$ [most are located postsynaptically (Miner et al., 2003)]. Overall, these data have raised doubts about the presynaptic mechanisms responsible for the excitatory actions of $5-\mathrm{HT}_{2} \mathrm{~A}$ receptors and suggest that postsynaptic receptors, which make up the majority of cortical $5-\mathrm{HT}_{2 \mathrm{~A}}$ receptors, are involved.

$5-\mathrm{HT}_{2 \mathrm{~A}}$ receptors seem to exert a more marked depolarizing action in early stages of postnatal development, since the depolarizing action of $5-\mathrm{HT}$ diminishes with age. Both $5-\mathrm{HT}_{2 \mathrm{~A}}$ and $5-\mathrm{HT}_{7}$ receptors appears to underlie the depolarizing effect of 5-HT (see below) (Zhang, 2003; Béique et al., 2004).

There is almost no evidence for a role of $5-\mathrm{HT}_{2} \mathrm{C}$ receptors in the modulation of cortical activity. 5-HT-induced slow excitations in prefrontal interneurons seem to be mediated exclusively by $5-\mathrm{HT}_{2 \mathrm{~A}}$ receptors, since the $5-\mathrm{HT}_{2 \mathrm{C}}$ antagonist SB242084 failed to reduce 5-HT excitations previously blocked by a 5-


described primary expression of $5-\mathrm{HT}_{2} \mathrm{C}$ receptors in pyramidal neurons. Consistently, in the piriform cortex, it was reported that 5-HT could activate pyramidal neurons via $5-\mathrm{HT}_{2} \mathrm{C}$ receptors and GABAergic neurons via $5-\mathrm{HT}_{2 \mathrm{~A}}$ receptors (Sheldon and Aghajanian, 1991). However, the depolarizing action of 5-HT in layer $\mathrm{V}$ pyramidal neurons of the $\mathrm{mPFC}$ does not seem to depend on $5-\mathrm{HT}_{2} \mathrm{C}$ receptor activation since it was not blocked by the selective antagonist SB 242084 (Béique et al., 2004). This inconsistency will require further investigation.

\section{5-HT 3 RECEPTORS}

5-HT can mediate rapid excitatory responses through the activation of the $5-\mathrm{HT}_{3 \mathrm{~A}}$ receptor, a ligand-gated ion channel. These receptors may be involved in cortical actions of 5-HT, since some $5-\mathrm{HT}_{3}$ receptor antagonists display procognitive effects (Staubli and $\mathrm{Xu}, 1995)$. These agents have been also reported to display anxiolytic and antipsychotic activity in animal models (Higgins and Kilpatrick, 1999) and to improve the therapeutic action of antipsychotic drugs in schizophrenic patients (Sirota et al., 2000). Likewise, the atypical antipsychotic clozapine is an antagonist of 5- $\mathrm{HT}_{3}$ receptors (Watling et al., 1989; Edwards et al., 1991).

Early microiontophoretic studies showed that 5-HT and 5$\mathrm{HT}_{3}$ receptor agonists suppressed pyramidal neuron activity in rat $\mathrm{PFC}$ through the activation of $5-\mathrm{HT}_{3}$ receptors by a direct action (Ashby et al., 1989b, 1991, 1992). However, more recent in vitro studies indicate that 5-HT may also increase pyramidal neurons IPSCs by activation of $5-\mathrm{HT}_{3}$ receptors, likely as a result 
of a fast synaptic excitation of local GABAergic neurons (Zhou and Hablitz, 1999; Férézou et al., 2002; Xiang and Prince, 2003). The latter observations are consistent with the presence of $5-\mathrm{HT}_{3}$ receptors in GABAergic interneurons in the rat telencephalon, including the PFC (Morales and Bloom, 1997; Puig et al., 2004). In macaque cortex, $5-\mathrm{HT}_{3}$ receptors are expressed by a subpopulation of calbindin- and calretinin-positive interneurons (Jakab and Goldman-Rakic, 2000). In vivo studies also show the excitation of GABA interneurons in the $\mathrm{mPFC}$ through $5-\mathrm{HT}_{3}$ receptors (Puig et al., 2004).

\section{OTHER 5-HT RECEPTORS}

There is almost no information on the effects of 5-HT or selective agonists on cortical neurons through the activation of $5-\mathrm{HT}_{4}$ $5-\mathrm{HT}_{7}$ receptors. For instance, it has been suggested that $5-\mathrm{HT}_{7}$ receptor may play a role during early postnatal developing of cortical circuits. In vitro whole cell recordings revealed a shift in the effect of 5-HT on membrane potential across development according with coordinated changes in the expression and function of $5-\mathrm{HT}_{1 \mathrm{~A}}, 5-\mathrm{HT}_{2 \mathrm{~A}}$, and $5-\mathrm{HT}_{7}$ receptors. Hence, $5-\mathrm{HT}$ in early postnatal days elicits a marked depolarization of pyramidal cells (dependent on $5-\mathrm{HT}_{2 \mathrm{~A}}$ and $5-\mathrm{HT}_{7}$ receptors) which progressively shifts to hyperpolarization (mediated by $5-\mathrm{HT}_{1 \mathrm{~A}}$ receptors). This change appears to be mainly due to the loss of $5-\mathrm{HT}_{7}$ receptors together with an increased function of $5-\mathrm{HT}_{1 \mathrm{~A}}$ receptors (Béique et al., 2004).

The activation of 5- $\mathrm{HT}_{4}$ receptors has dual effects (enhancement or reduction) on GABA evoked currents in PFC pyramidal neurons, being the direction of the $5-\mathrm{HT}_{4}$ receptor-mediated effect determined by neuronal activity. These observations suggest a flexible mechanism for $5-\mathrm{HT}_{4}$ receptors to dynamically regulate synaptic transmission and neuronal excitability in the PFC network (Cai et al., 2002b; Yan, 2002). Also, extracellular recordings in rat frontal cortical slices have showed that bursting activity could be modulated by the application of the $5-\mathrm{HT}_{4}$ agonist zacopride. Thus, perfusion of zacopride induces an increase on spontaneous bursting activity (Zahorodna et al., 2004).

Blockade of 5- $\mathrm{HT}_{6}$ receptors improves cortical performance in different learning and memory paradigms, an effect still poorly understood (Upton et al., 2008). Recent work using whole-cell path-clamp electrophysiological recordings showed that $5-\mathrm{HT}_{6}$ agonists reversibly reduced spontaneous glutamatergic transmission in both striatal and layer V PFC pyramidal neurons, an effect prevented by preincubation in the selective $5-\mathrm{HT}_{6}$ antagonists SB258585. Since no evidence for the expression of $5-\mathrm{HT}_{6}$ receptors on glutamatergic neurons has been provided and it has been reported co-localization of this receptor on GAD immunoreactive neurons (Woolley et al., 2004) these data suggest that modulation of the glutamatergic transmission might be mediated by 5- $\mathrm{HT}_{6}$ receptors expressed by GABAergic neurons (Tassone et al., 2011).

\section{In vivo ACTIONS OF ENDOGENOUS SEROTONIN ON CORTICAL NEURONS}

Despite the wealth of in vitro studies on the actions of 5-HT on cortical neurons, the endogenous effects of $5-\mathrm{HT}$ and its receptors in the regulation of cortical inhibitory and excitatory responses in vivo is not fully known. The effect of endogenous 5-HT on postsynaptic $5-\mathrm{HT}_{1 \mathrm{~A}}$ receptors has been typically examined in two forebrain areas, the CA region of the hippocampal formation and the mPFC using extracellular recordings. Electrical stimulation of the medial forebrain bundle inhibits hippocampal pyramidal neurons, an effect reversed by $5-\mathrm{HT}_{1 \mathrm{~A}}$ receptor blockade (Chaput and de Montigny, 1988). Similarly, as previously observed with the microiontophoretic application of 5-HT (see above), the electrical stimulation of DR/MnR at a physiological rate $(\sim 1$ spike/s) mainly evoked inhibitory responses in PFC cells in vivo, which were partly or totally blocked by the selective 5- $\mathrm{HT}_{1 \mathrm{~A}}$ antagonist WAY-100635 (Hajós et al., 2003; AmargósBosch et al., 2004; Puig et al., 2005, 2010). DR/MnR stimulation mainly evoked $5-\mathrm{HT}_{1 \mathrm{~A}}$-mediated inhibitory responses in two thirds of pyramidal neurons of the mPFC, identified by antidromic activation from the midbrain. The rest of responses were orthodromic excitations, either pure $(13 \%)$ or preceded by short-latency inhibitions (20\%, i.e., biphasic responses) (Puig et al., 2005) (Figure 6). Excitatory responses were blocked by the selective 5- $\mathrm{HT}_{2 \mathrm{~A}}$ receptor antagonist M100907 (Amargós-Bosch et al., 2004; Puig et al., 2005).

Intriguingly, the proportion of excitatory responses was markedly lower than that of inhibitory responses despite the $\sim 80 \%$ co-expression of $5-\mathrm{HT}_{1 \mathrm{~A}}$ and $5-\mathrm{HT}_{2 \mathrm{~A}}$ receptor mRNAs in PFC neurons (Amargós-Bosch et al., 2004). This observation agrees with the predominant inhibitory effects of 5-HT on cortical neurons observed in vitro (see above). The putative differential location of $5-\mathrm{HT}_{1 \mathrm{~A}}$ and $5-\mathrm{HT}_{2 \mathrm{~A}}$ receptors in different compartments of pyramidal neurons may perhaps account for the greater proportion of inhibitory responses. Should $5-\mathrm{HT}_{1 \mathrm{~A}}$ receptor be localized on axon hillocks, endogenous 5-HT would have a profound suppressing effect on action potential generation. Alternatively, a direct effect of $5-\mathrm{HT}_{1 \mathrm{~A}}$ receptor on ionic conductances $\left(\uparrow \mathrm{K}^{+}\right.$currents) may favor inhibitory vs. excitatory actions of 5-HT mediated by $5-\mathrm{HT}_{2 \mathrm{~A}}$ receptors, which result from indirect and long lasting changes of similar ionic conductances into the opposite direction $\left(\downarrow \mathrm{K}^{+}\right.$currents, $\uparrow \mathrm{Ca} 2^{+}$currents). Interestingly, $5-\mathrm{HT}_{1 \mathrm{~A}}$ and $5-\mathrm{HT}_{2 \mathrm{~A}}$ receptor mRNAs do not colocalize in parvalbumin-expressing inhibitory neurons of the PFC (Puig et al., 2010). This supports the notion that $5-\mathrm{HT}_{1 \mathrm{~A}}$ receptors in pyramidal neurons, by down-regulating action potential output, and $5-\mathrm{HT}_{2 \mathrm{~A}}$ receptors, by enhancing synaptic inputs onto the dendrites, exert a balanced modulation of cortical pyramidal networks across layers not available to small local interneurons (Puig and Gulledge, 2011).

In addition, inhibitory responses elicited in MPFC pyramidal neurons by raphe stimulation involve a GABAergic component since they were blocked by WAY- 100635 but also by the $\mathrm{GABA}_{\mathrm{A}}$ antagonist picrotoxinin (Puig et al., 2005). This GABAergic response may indeed result from the activation of local GABA interneurons by axon collaterals of pyramidal neurons projecting to midbrain. Likewise, 5-HT may also activate PFC GABAergic neurons through $5-\mathrm{HT}_{2 \mathrm{~A}}$ receptors thus inhibiting pyramidal cell activity, as observed in vitro (Zhou and Hablitz, 1999). The activation of $5-\mathrm{HT}_{3}$ receptors is also likely, given their involvement in the excitatory responses of a subpopulation of GABAergic 


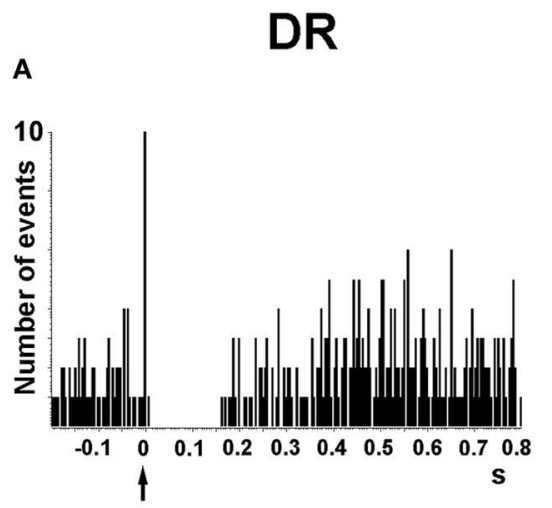

C
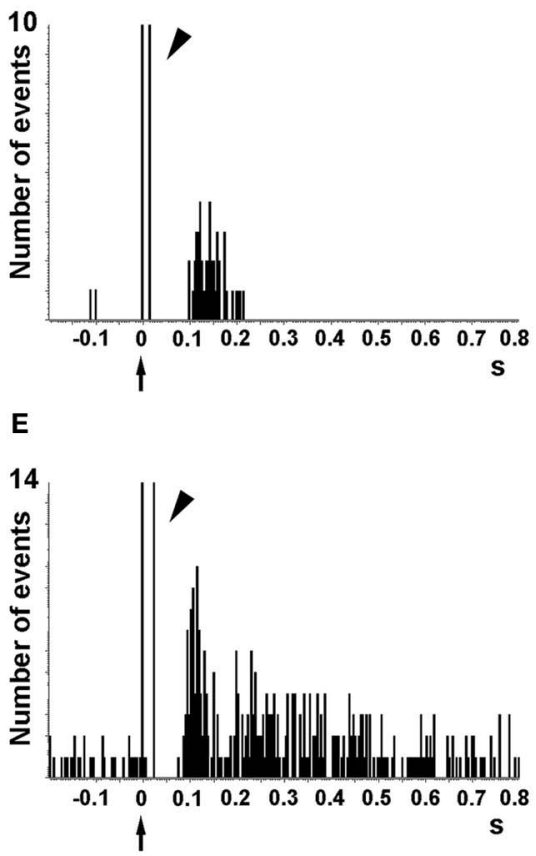

FIGURE 6 | Representative examples of the responses evoked in pyramidal neurons of the anterior cingulate and prelimbic areas of the mPFC by the electrical stimulation of the DR and MnR. (A,B) Short latency long duration inhibitory responses. (C,D) Pure excitatory responses, which are often seen in pyramidal neurons with a low firing rate. These orthodromic excitations have a similar duration after DR or MnR stimulation but the latency is significantly lower after MnR stimulation, as in the example seen in the figure. (E,F) Examples of orthodromic excitations response

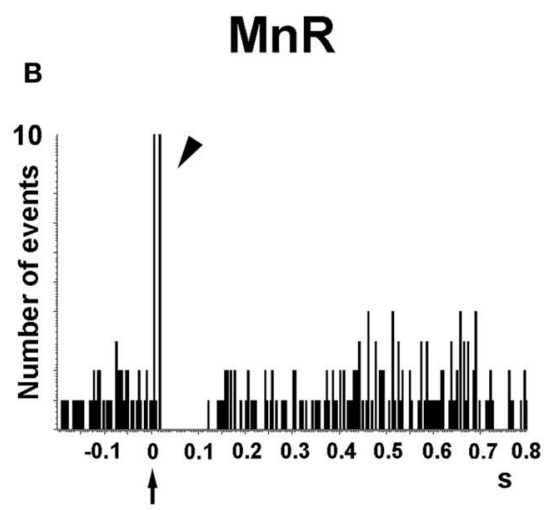

D
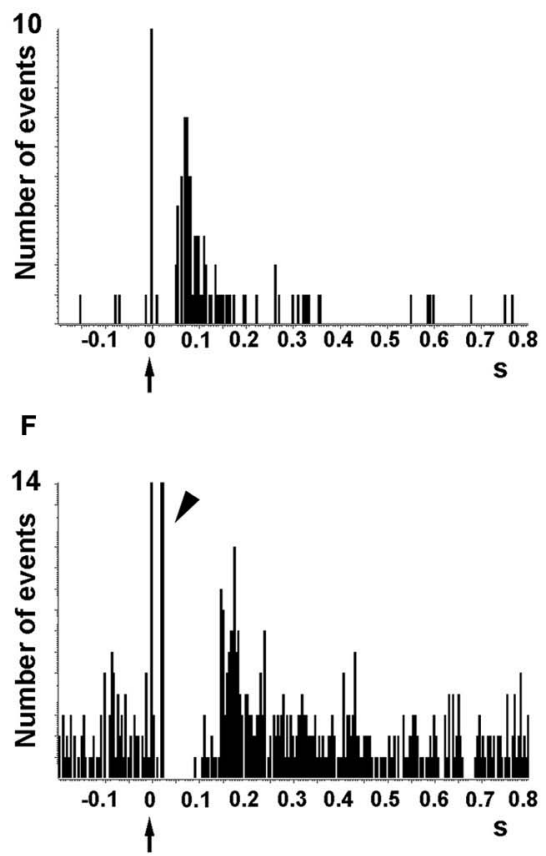

preceded by short latency inhibitions (biphasic responses). Note the

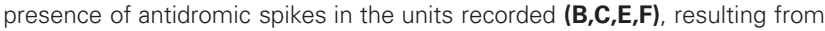
the presence of a dense connectivity between the PFC and the DR/MnR. The units in (A) and (D) were antidromically activated at currents higher than those used to evoke a pyramidal response. Each peristimulus time histogram consists of 110 triggers ( $2 \mathrm{~min}$ ). Bin size $=4 \mathrm{~ms}$. The arrow in the abcissa denotes the stimulus artifact (time 0). The arrowheads indicate antidromic spikes. Reproduced with permission from Puig et al. (2005). interneurons (Puig et al., 2004; see above). However, a third element seems also likely to explain the inhibition given the very short latency of inhibitory responses ( $9 \mathrm{~ms}$ on average) induced by $\mathrm{DR} / \mathrm{MnR}$ stimulation. This latency is shorter than the time required for action potentials to travel along 5-HT axons from midbrain to PFC (orthodromic potentials; $\sim 25 \mathrm{~ms}$ ) or pyramidal axons from PFC to midbrain (antidromic potentials; $\sim 15 \mathrm{~ms}$ ). Overall, these observations would be consistent with the existence of a monosynaptic GABAergic projection from the midbrain raphe to $\mathrm{mPFC}$, as suggested by anatomical studies (Jankowski and Sesack, 2002). This pathway would be analogous to the ascending GABAergic pathway between the ventral tegmental area and the mPFC or the nucleus accumbens-mesocortical and mesolimbic pathways, respectively-(Carr and Sesack, 2000), suggesting a common pattern of control of PFC by monoaminergic nuclei in which monoamine and projection GABA neurons would be involved.

Similarly to pyramidal neurons, endogenous 5-HT elicits $5-\mathrm{HT}_{1 \mathrm{~A}}$ receptor-mediated inhibitions and $5-\mathrm{HT}_{2 \mathrm{~A}}$ receptormediated excitations in PFC parvalbumin-expressing fast-spiking interneurons in vivo (Puig et al., 2010). There is also evidence that $5-\mathrm{HT}_{3}$ receptors can activate $\mathrm{GABA}$ interneurons in the rat 
PFC in vivo. Physiological stimulation of the raphe nuclei excites local GABAergic neurons located in superficial layers (I-III) of the prelimbic and cingulate areas. These responses can clearly be distinguished from $5-\mathrm{HT}_{2 \mathrm{~A}}$ receptor-mediated excitations because they (a) have shorter onset latency and duration than $5-\mathrm{HT}_{2 \mathrm{~A}}$ receptor-mediated excitations, (b) show a higher concordance rate (number of spikes evoked/number of stimulus delivered in $\mathrm{DR} / \mathrm{MnR}$ ), and (c) are blocked by of the $5-\mathrm{HT}_{3}$ receptor antagonists ondansetron and tropisetron (Puig et al., 2004; Puig and Gulledge, 2011).

In summary, three possibilities (differential localization and/or control of ion flows by $5 \mathrm{HT}_{1 \mathrm{~A}}$ and $5-\mathrm{HT}_{2 \mathrm{~A}}$ receptors in pyramidal neurons, existence of a raphe-mPFC GABAergic pathway, and inhibitory action in pyramidal cells mediated by activation of excitatory 5-HT receptors on GABAergic interneurons), not mutually exclusive, may account for the predominantly inhibitory responses elicited by raphe stimulation on pyramidal neurons of the $\mathrm{mPFC}$. To the best of our knowledge, in vivo responses to other 5-HT receptors present in low or moderate abundances in cortex, such as $5-\mathrm{HT}_{2} \mathrm{C}, 5-\mathrm{HT}_{4}, 5-\mathrm{HT}_{6}$, or $5-\mathrm{HT}_{7}$ have not been reported so far.

\section{SEROTONIN MODULATES CORTICAL NETWORK ACTIVITY}

Neuronal populations, via their anatomical and functional interconnections, can display sophisticated discharge patterns that arise from the synchronization of their activity. That is, they can form neural networks whereby synchronous activity can become oscillatory. Oscillatory activities, ranging from 0.1 up to few hundred cycles per second, generate small electrical waves detectable outside the skull through electroencephalographic (EEG) recordings or intracerebrally through local field potential (LFP) recordings. Oscillations at several frequency bands have been recorded in the neocortex during natural sleep, anesthesia, and alertness, where their presence tightly correlates with a variety of behavioral tasks. During slow-wave sleep (SWS) and deep anesthesia, slow waves $(\sim 2 \mathrm{~Hz})$ and delta waves $(1-4 \mathrm{~Hz})$ are prominent (Steriade et al., 1993; Mukovski et al., 2007; Celada et al., 2008; Puig et al., 2010), which are critical for memory consolidation and learning (Stickgold, 2005; Marshall et al., 2006; Landsness et al., 2009). During wakefulness, cortical alpha $(10-14 \mathrm{~Hz})$ and gamma $(30-80 \mathrm{~Hz})$ waves correlate with the modulation of attention, memory, and learning (Fries et al., 2001; Jensen et al., 2002; Ward, 2003; Buschman and Miller, 2007; Fries, 2009; Siegel et al., 2009; Benchenane et al., 2011; Bollimunta et al., 2011; Puig and Miller, 2012), whereas beta waves $(15-30 \mathrm{~Hz}$ ) also play a role in learning (Puig and Miller, 2012). Work reported over the last decade has suggested that the synchronization of neural activity in the neocortex and subcortical structures such as the hippocampus may indeed be critical for the normal processing of cognitive functions. In fact, schizophrenia patients, who show clear cognitive impairment (Elvevåq and Goldberg, 2000; Harvey et al., 2001), display abnormal cortical oscillatory activity in the slow and gamma frequency bands (Hoffmann et al., 2000; Spencer et al., 2003; Cho et al., 2006). Likewise, abnormal cortical oscillations can be observed in a variety of psychiatric disorders (see below). Considering the growing evidence pointing to an important role of cortical oscillations in cognition and the abundant psychiatric medication targeting the serotonergic system, the involvement of 5-HT in the generation and modulation of cortical oscillatory activities is of high interest, as it will help to identify new targets for psychiatric treatments.

\section{SEROTONERGIC MODULATION OF CORTICAL OSCILLATIONS}

The seminal studies pioneered by Mircea Steriade and colleagues (Steriade et al., 1993, 1996, 2001; Steriade, 2006) described in detail the cellular mechanisms underlying the spontaneous slow rhythms $(\sim 2 \mathrm{~Hz})$ - including slow and spindle waves-present in the neocortex during natural sleep. Slow waves reflect the spontaneous changes in membrane potential and synchronous firing of neuronal ensembles coordinated by an underlying slow oscillation. At a cellular level, they consist of an alternation between periods of activity (called UP states) and silence (DOWN states), that are not observed during wakefulness. UP and DOWN states reflect periods of membrane depolarization and hyperpolarization, respectively, within large neuronal networks (Steriade et al., 1993; Contreras and Steriade, 1995; Mukovski et al., 2007). Spontaneous low frequency oscillations $(\sim 1 \mathrm{~Hz})$ have also been reported to occur in slices of the ferret visual cortex (SanchezVives and McCormick, 2000), suggesting the existence of intrinsic mechanisms. To our knowledge, the role of 5-HT in the modulation of cortical slow oscillations during natural sleep has not been addressed, despite the marked activity changes of raphe 5-HT neurons during sleep and wakefulness.

Mild anesthetics, such as chloral hydrate, can reliably generate slow oscillations in the neocortex of laboratory animals that resemble the slow rhythms of natural SWS. This provides a more convenient preparation to examine how synchronous activity is modulated by $5-\mathrm{HT}$ and its receptors. Endogenous 5-HT-released after electrical stimulation of the DR in the midbrain - modulates both the frequency and amplitude of cortical slow-like oscillations recorded in the PFC of anesthetized rats (Puig et al., 2010). 5-HT release produces a moderate increase in frequency by promoting rapid initiation of UP states, while reducing the amplitude and duration of DOWN states (Figure 7). This indicates that the activity of 5-HT neurons in the DR (and possibly MnR) may directly regulate the frequency of cortical slow oscillations by promoting UP states. Thus, despite most pyramidal neurons are inhibited by the physiological release of 5-HT (see above), 5-HT appears to have an excitatory effect on cortical networks in vivo, because UP states are generated by the synchronous depolarization of large ensembles of cortical neurons. In fact, a massive release of 5-HT in the cortex following high-frequency stimulation of the DR completely suppresses cortical slow waves by promoting a long-lasting depolarization and elimination of DOWN states (Puig et al., 2010). These excitatory influences of 5$\mathrm{HT}$ on cortical slow oscillations may be accomplished via $5-\mathrm{HT}_{2 \mathrm{~A}}$ receptors (Celada et al., 2008; Puig et al., 2010). Hence, pharmacological stimulation of $5-\mathrm{HT}_{2 \mathrm{~A}}$ receptors with the hallucinogen and $5-\mathrm{HT}_{2 \mathrm{~A}}$ receptor agonist DOI and the blockade with the 5$\mathrm{HT}_{2 \mathrm{~A} / 2 \mathrm{C}}$ antagonist ritanserin desynchronize slow waves in rat PFC (Figure 8), suggesting that a balanced stimulation of 5- $\mathrm{HT}_{2 \mathrm{~A}}$ receptors is critical for a stable synchronization of cortical slow waves.

Much less is known about the role of 5-HT in the modulation of high-frequency oscillations, especially for the alpha 


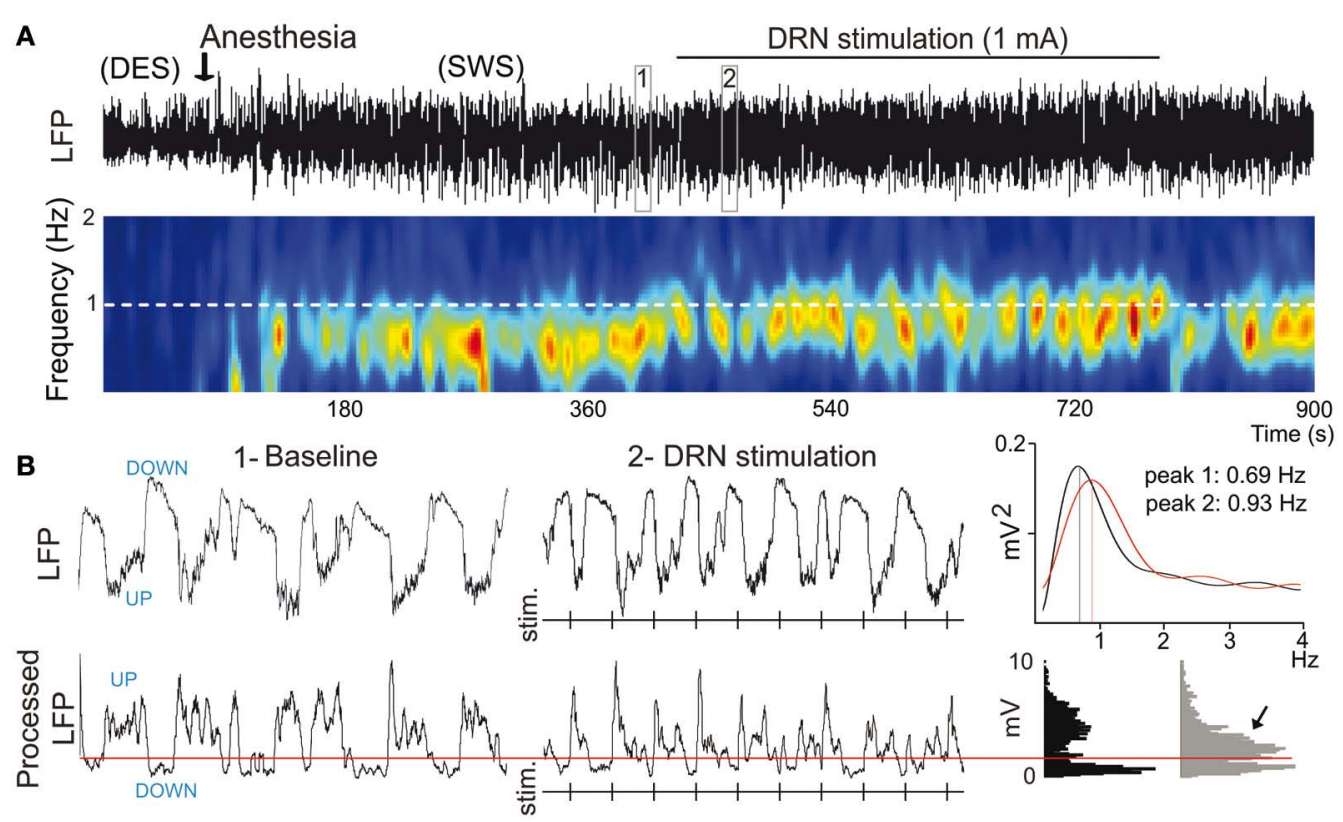

FIGURE 7 | 5-HT modulates slow waves in the PFC. (A) Stimulation of the dorsal raphe nucleus (DRN) increases the frequency of cortical slow waves $(<1 \mathrm{~Hz})$. Top, Local field potential (LFP) signal showing an epoch of desynchronization (absence of slow waves) preceding anesthesia-induced slow-wave sleep (SWS), during which the DRN was stimulated electrically at $1 \mathrm{~Hz}$. Boxes 1 and 2 are expanded in (B). Bottom, Change in power of slow waves over time (red indicates high power, blue low power). White dashed line marks the frequency of stimulation. Note that the predominant band $(\sim 0.7 \mathrm{~Hz})$ increases in frequency toward the frequency of stimulation during DRN stimulation. (B) Top, expanded 10-s traces from (A). Vertical lines correspond to times of DRN stimulation. Power spectra for 1 min segments that contain the 10-s traces in boxes 1 and 2 are shown on the far right. Bottom, LFPs were processed off-line for an accurate measure of UP-state duration. A threshold was set (red line) to discriminate UP states. Note the increase in UP-state potentials during the stimulations (arrow). Modified from Puig et al. (2010).
$(10-14 \mathrm{~Hz})$ and beta $(15-30 \mathrm{~Hz})$ bands. A correlation between increases in the power of alpha oscillations in the ventral PFC and increased levels of 5-HT in whole blood has been found (Fumoto et al., 2010; Yu et al., 2011). Some more information has been reported on gamma oscillations. During natural sleep and anesthesia, gamma oscillations $(30-100 \mathrm{~Hz})$ are present in cortex along with slow waves (Steriade, 2006; Puig et al., 2010; Massi et al., 2012), although their specific involvement in cortical processing is poorly understood. Gamma oscillations are generated by the synchronous firing of fast-spiking interneuron networks (Cardin et al., 2009; Sohal et al., 2009), which exert potent inhibition onto pyramidal neurons and other fast-spiking neurons.

Interestingly, 5-HT exerts a strong modulation of gamma oscillations in the PFC of anesthetized rats via $5-\mathrm{HT}_{1 \mathrm{~A}}$ and $5-\mathrm{HT}_{2 \mathrm{~A}}$ receptors (Puig et al., 2010). Specifically, blockade of $5-\mathrm{HT}_{1 \mathrm{~A}}$ receptors increases the amplitude of cortical gamma waves, the discharge rate of $5-\mathrm{HT}_{1 \mathrm{~A}}$-expressing fast-spiking interneurons, and sharpens the synchronization of these neurons to gamma cycles. By contrast, blocking $5-\mathrm{H}_{2 \mathrm{~A}}$ receptors decreases cortical gamma oscillations and desynchronizes 5$\mathrm{HT}_{2 \mathrm{~A}}$-expressing fast-spiking interneurons from gamma waves. In other words, endogenous 5-HT can dampen or enhance gamma oscillations by reducing or increasing the activity and synchronization of $5-\mathrm{HT}_{1 \mathrm{~A}}$ - and $5-\mathrm{HT}_{2 \mathrm{~A}}$-expressing fast-spiking interneurons, respectively. Overall, 5-HT's major effect is a reduction of cortical gamma oscillations during sleep-like epochs. Further investigations should establish whether these actions also occur during wakefulness.

\section{RELEVANCE FOR PSYCHIATRIC DISORDERS}

Abnormal oscillatory activities in the cortex have been observed in a number of neurological and psychiatric disorders (Basar and Güntekin, 2008). For example, the synchronization of slow $(<1 \mathrm{~Hz})$, delta $(1-4 \mathrm{~Hz})$ and gamma $(30-80 \mathrm{~Hz})$ oscillations is reduced in schizophrenia, major depression, and bipolar disorder (Keshavan et al., 1998; Hoffmann et al., 2000; Spencer et al., 2003; Cho et al., 2006; Uhlhaas and Singer, 2006). Impaired gamma oscillations and synchrony have also been reported in schizophrenia patients as well, suggesting the existence of network alterations (Spencer et al., 2003; Cho et al., 2006; Uhlhaas and Singer, 2006; Basar and Güntekin, 2008; Gonzalez-Burgos and Lewis, 2008; Gonzalez-Burgos et al., 2010).

Interestingly, patients with depression that do not respond to selective serotonin reuptake inhibitors (SSRIs) have alterations in alpha power in some cortical areas compared with responders and healthy control subjects (Bruder et al., 2008), suggesting some relationship between 5 -HT levels and the amplitude of alpha oscillations.

Animal models of psychiatric disorders are starting to shed new light into the contribution of 5-HT to normal and abnormal cortical oscillations. Importantly, they are providing valuable 

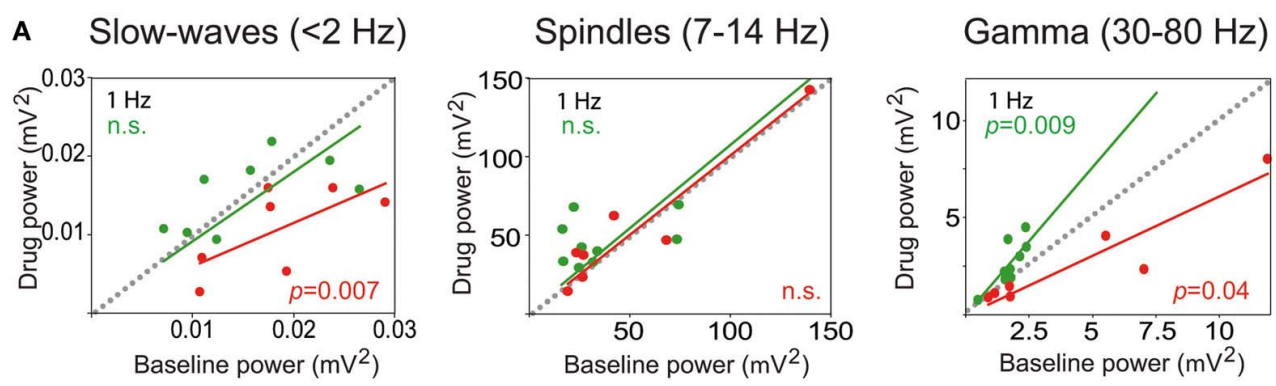

\section{B Slow waves}

5-HT1AR antagonist (WAY-100635)
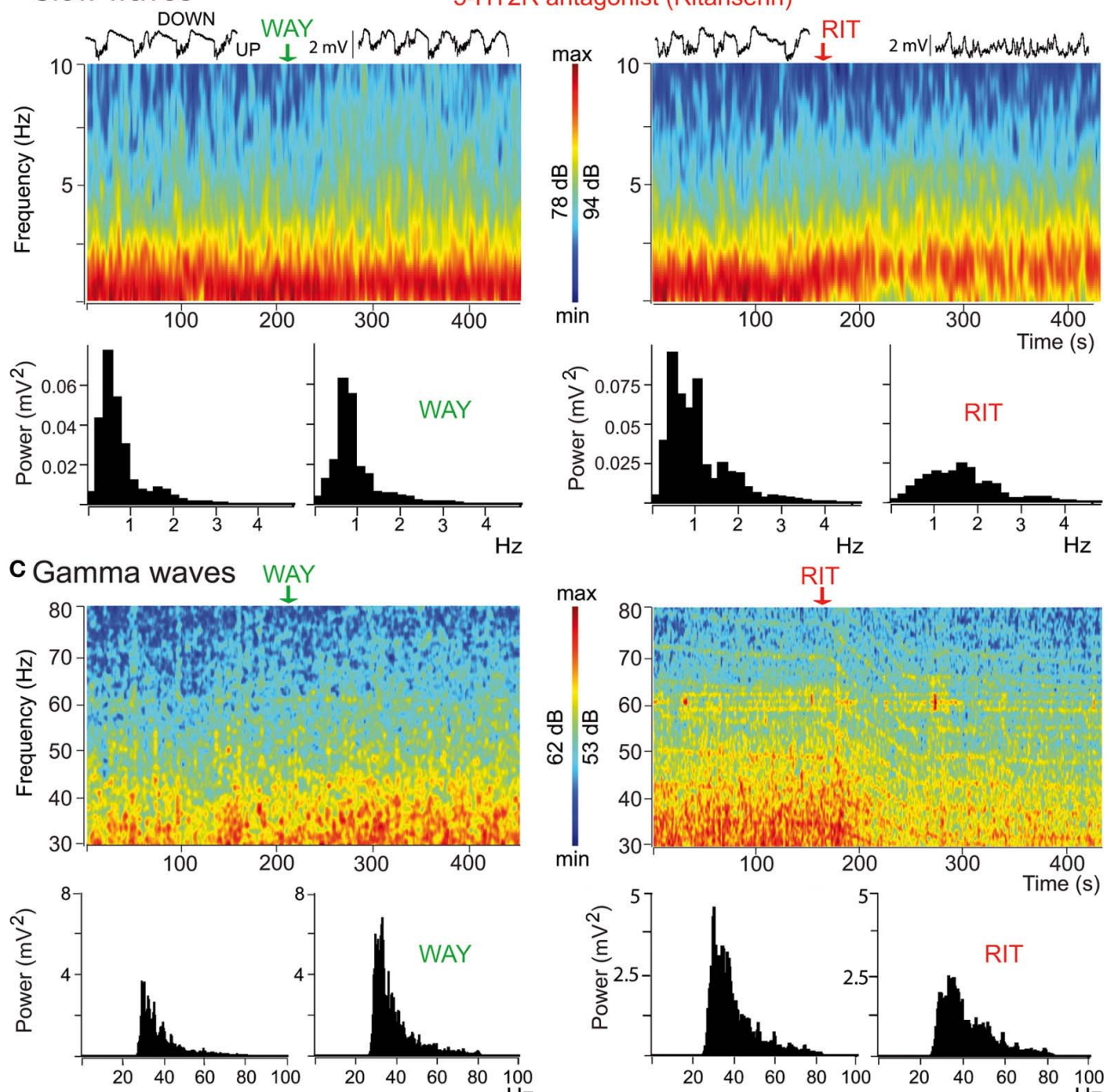

FIGURE 8 | Distinct modulation of cortical synchrony by $5-\mathrm{HT}_{1 \mathrm{~A}}$ and 5- $\mathbf{H T}_{2 \mathrm{~A} / 2 \mathrm{C}}$ receptors. (A) Effects of the $5-\mathrm{HT}_{1 \mathrm{~A}}$ antagonist WAY (green) and the $5-\mathrm{HT}_{2 \mathrm{~A} / 2 \mathrm{C}} \mathrm{R}$ antagonists ritanserin (RIT, red) on the baseline power (comparison of $30 \mathrm{~s}$ epochs before and after drug injection) of slow, spindle, and gamma oscillations. Note the opposing actions of the two drugs on the power of gamma oscillations. (B) Examples of the effects of WAY and RIT on the power of slow waves. Time-frequency

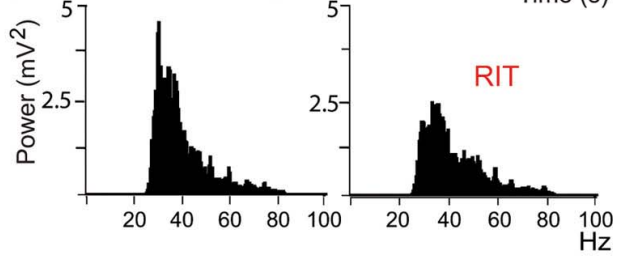

plots and corresponding quantification of the power. WAY did not change significantly the power of slow-waves but RIT markedly reduced it. Red depicts high power, blue low power. Representative $10 \mathrm{~s}$ traces of the LFPs are shown on top of the spectrograms. (C) Examples of the effects of WAY and RIT on the power of gamma waves (same examples as in B). WAY augmented, whereas RIT reduced, the power of gamma oscillations. Modified from Puig et al. (2010).

information to better understand the cellular mechanisms by which psychiatric medication compensates for imbalances in network activity. For instance, the hallucinogen and preferential 5- $\mathrm{HT}_{2 \mathrm{~A}}$ receptor agonist DOI disrupts low-frequency oscillations in the PFC of anesthetized rats (Celada et al., 2008), an effect reversed by antipsychotic drugs with different pharmacological targets. While the effect of clozapine can be interpreted by its competition with DOI at $5-\mathrm{HT}_{2 \mathrm{~A}}$ receptors, the effect of 
haloperidol must necessarily be interpreted at the network level, given its inability to occupy $5-\mathrm{HT}_{2 \mathrm{~A}}$ receptors at the dose used. A reduction in slow wave activity has been detected in patients with schizophrenia during sleep (Hoffmann et al., 2000); hence, a potential source of this decrease could be an unbalanced stimulation of cortical $5-\mathrm{HT}_{2 \mathrm{~A}}$ receptors.

Interestingly, the disruption of PFC activity evoked by DOI is similar-yet of smaller magnitude-to that produced by the NMDA receptor antagonist phencyclidine (PCP) (Kargieman et al., 2007). Interestingly, PCP effect is also reversed by haloperidol and clozapine, which suggests a link between the disrupting action of PCP and DOI on PFC activity and their psychotomimetic activity. Likewise, the reversal of this effect by two antipsychotic drugs with different primary targets strongly suggests a relationship with their therapeutic action. Despite its low in vitro affinity for $5-\mathrm{HT}_{1 \mathrm{~A}}$ receptors, the reversal by clozapine of PCP effects depends on the in vivo stimulation of such receptors (Kargieman et al., 2012), as previously observed for the antipsychotic-evoked release of dopamine in mPFC (Diaz-Mataix et al., 2005).

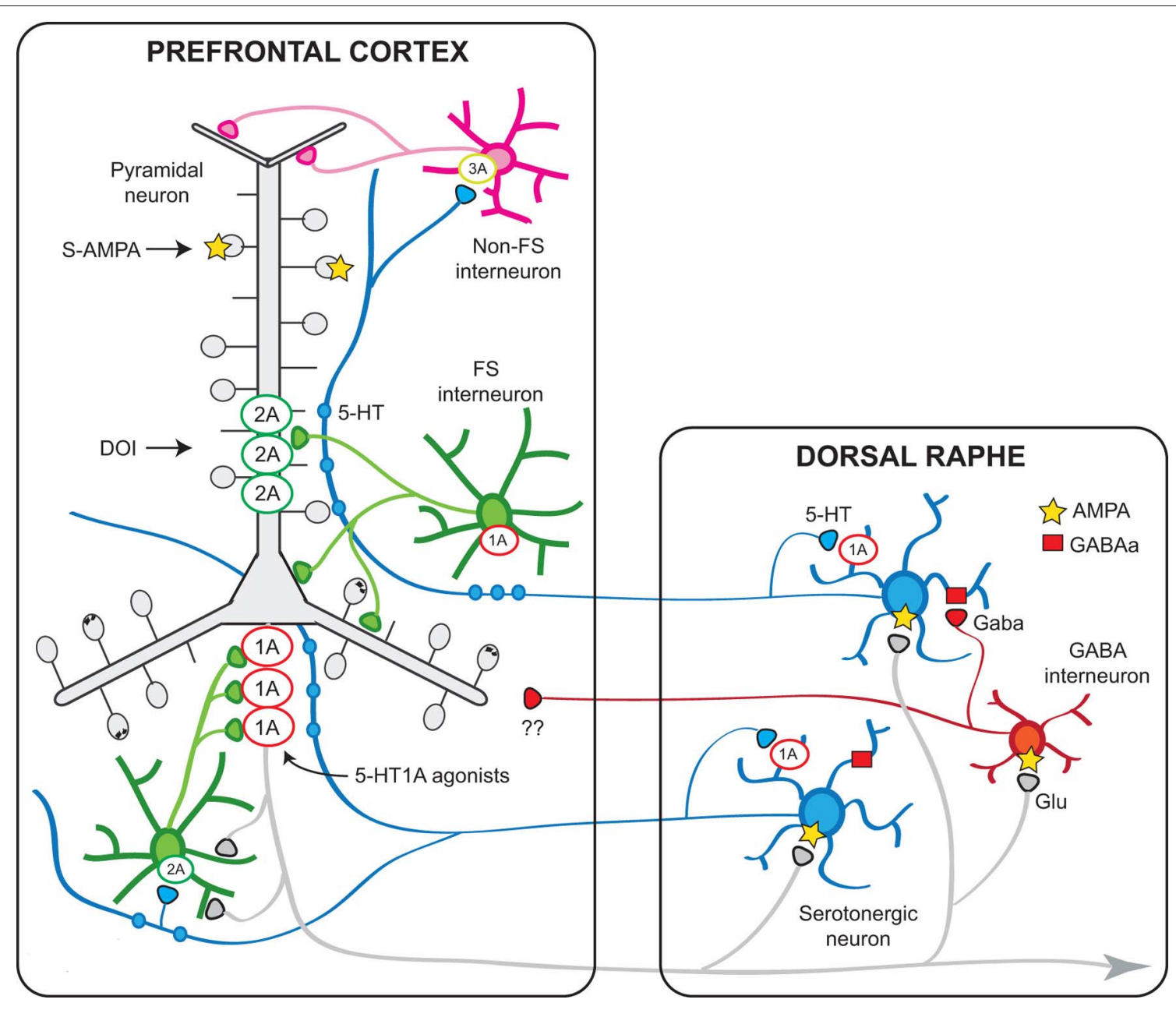

FIGURE 9 | Schematic representation of the relationships between the mPFC and the DR involving $5-\mathrm{HT}_{1 \mathrm{~A}}$ and $5-\mathrm{HT}_{2 \mathrm{~A}}$ receptors. Pyramidal neurons in the mPFC project densely to the $\mathrm{DR} / \mathrm{MnR}$ and modulate the activity of serotonergic neurons via direct and indirect influences (Celada et al., 2001). In turn, endogenous 5-HT modulates pyramidal cell activity through the activation of various receptors expressed in the neocortex, of which $5-\mathrm{HT}_{1 \mathrm{~A}}$ and $5-\mathrm{HT}_{2 \mathrm{~A}}$ receptors play a major role. The latter receptors are particularly enriched in apical dendrites of pyramidal neurons where they can facilitate AMPA inputs. A smaller population of $5-\mathrm{HT}_{2 \mathrm{~A}}$ receptors are expressed by GABA interneurons, including fast-spiking (FS) interneurons. Pyramidal $5-\mathrm{HT}_{1 \mathrm{~A}}$ receptors may be localized in the axon hillock, together with GABAA receptors activated by chandelier axons (Azmitia et al., 1996; De Felipe et al., 2001; Cruz et al., 2004) or in the somatodendritic compartment (Riad et al., 2000). It is possible that $5-\mathrm{HT}$ axons reaching the cortex at different levels may exert distinct effects on pyramidal neurons, depending on a precise topology between certain $5-\mathrm{HT}$ neurons or neuronal clusters within the $\mathrm{DR} / \mathrm{MnR}$ and $5-\mathrm{HT}_{1 \mathrm{~A}^{-}}$or $5-\mathrm{HT}_{2 \mathrm{~A}}$-receptor-rich compartments, in agreement with anatomical studies showing an association between 5-HT axons and such receptor-rich areas (De Felipe et al., 2001; Jansson et al., 2001). Also, 5-HT axons reaching upper layers, including layer I, may activate $5-\mathrm{HT}_{3}$ receptors located on GABAergic non-FS interneurons to modulate inputs onto the tufts and most distant segments of apical dendrites of pyramidal neurons. $5-\mathrm{HT}_{1 \mathrm{~B}}$ receptors are present on serotonergic axons (not shown) and in axons of other neuronal types (e.g., glutamatergic) where they regulate neurotransmitter release and modulate synaptic activity. The scheme shows also the putative GABAergic projections from DR/MnR to the mPFC suggested by electrophysiological and anatomical studies (see text). 
Collectively, these studies highlight the importance of 5-HT in regulating cortical network activity, as well as the complexities of the alterations present in psychiatric disorders and the compensatory mechanisms mediating the action of psychiatric medication. Detailed knowledge of the cellular and circuit mechanisms underlying serotonergic modulation of cortical oscillations in health and disease could provide valuable information for our understanding of why many schizophrenia and other psychiatric treatments are largely ineffective at restoring PFC function.

\section{CONCLUSIONS}

The assessment of the in vivo and in vitro actions of 5-HT on cortical neurons and networks has revealed a complex pattern of action. 5-HT can hyperpolarize pyramidal neurons through the activation of $5-\mathrm{HT}_{1 \mathrm{~A}}$ receptors, an action that results from the opening of $\mathrm{G}$ protein-coupled inward rectifying $\mathrm{K}^{+}$channels. This effect is followed by a reduction of the firing activity of pyramidal neurons. At the same time, 5-HT can depolarize the same neurons through $5-\mathrm{HT}_{2 \mathrm{~A}}$ receptors and increase their excitability. These two receptors appear to be the main players for the postsynaptic actions of 5-HT in the cerebral cortex. In situ hybridization studies have revealed the concurrent presence of 5$\mathrm{HT}_{1 \mathrm{~A}}$ and $5-\mathrm{HT}_{2 \mathrm{~A}}$ receptor $\mathrm{mRNAs}$ in a large proportion $(\sim 80 \%)$ of neurons in the PFC. Although several hypotheses have been put forward, it is yet unclear what determines whether a given pyramidal neuron responds to 5-HT with an excitation or an inhibition, although the latter responses predominate, both in vitro and in vivo. However, the fact that 5-HT induces depolarizing actions on slow oscillations in vivo suggests that it can exert excitatory effects on cortical neural networks independent from action potential generation, a view awaiting further confirmation. The role of these two receptors in the modulation of the activity of GABAergic interneurons is still poorly understood. A significant proportion of these neurons, including fast-spiking interneurons, located in layers II-VI express $5-\mathrm{HT}_{1 \mathrm{~A}}$ and/or 5$\mathrm{HT}_{2 \mathrm{~A}}$ receptors; yet so far, there are no studies examining the role of both receptors in the modulation of ion currents. In vivo, $5-\mathrm{H}_{1 \mathrm{~A}}$ receptors decrease, whereas $5-\mathrm{HT}_{2 \mathrm{~A}}$ receptors increase, spiking rate of fast-spiking interneurons in the PFC (Puig et al., 2010).

On the contrary, there is a reasonable knowledge on the role of $5-\mathrm{HT}_{3}$ receptors in the control of the activity of GABAergic interneurons. It seems like there is a segregation

\section{REFERENCES}

Adell, A., Celada, P., Abellán, M. T., and Artigas, F. (2002). Origin and functional role of the extracellular serotonin in the midbrain raphe nuclei. Brain Res. Rev. 39, 154-180.

Aghajanian, G. K., and Lakoski, J. M. (1984). Hyperpolarization of serotonergic neurons by serotonin and LSD: studies in brain slices showing increased $\mathrm{K}+$ conductance. Brain Res. 305, 181-185.

Aghajanian, G. K., and Marek, G. J. (1997). Serotonin induces

of $5-\mathrm{HT}_{1 \mathrm{~A}} / 5-\mathrm{HT}_{2 \mathrm{~A}}$ receptors on one side, expressed likely in parvalbumin- and calbindin-containing interneurons and $5-\mathrm{HT}_{3}$ receptors, expressed in calretinin- and (to a lesser extent) calbindin-containing neurons. Moreover, interneurons expressing $5-\mathrm{HT}_{3}$ receptors are localized mostly in layers I-III, which suggests a role in the modulation of inputs reaching the tufts and upper segments of the apical dendrites of pyramidal neurons.

Another 5-HT receptor for which a role (yet still poorly characterized) has been attributed is the $5-\mathrm{HT}_{1 \mathrm{~B}}$ receptor, whose activation by 5 -HT can presynaptically modulate GABAergic and glutamatergic inputs onto pyramidal neurons. Figure 9 shows a schematic representation of the PFC_raphe circuit with the most important receptors involved in the serotonergic actions in PFC and their presumed localization.

Unfortunately, there is a poor knowledge of the actions of 5-HT on other receptors, some of which are expressed in significant amounts in the neocortex. $5-\mathrm{HT}_{2} \mathrm{C}$ receptors can modulate the activity of pyramidal neurons in piriform cortex, but this does not seem to be the rule in neocortex. On the other hand, the neuronal depolarization induced by $5-\mathrm{HT}_{7}$ receptor activation disappears few weeks after birth, which suggests a role in development but not in adulthood. Further studies are indeed required to clarify the complex role of 5-HT in the modulation of cortical activity. Current and new knowledge in this area will help to understand the involvement of 5-HT in cortical functions, notably those in PFC, a brain region highly enriched of 5-HT elements and involved in critical brain functions such as cognition and emotional control, among others.

\section{ACKNOWLEDGMENTS}

Supported by grants SAF 2012-35183 (Ministry of Economy and Competitiveness and EU FEDER funds), PI09/1245 and PI12/00156 (PN de I+D+I 2008-2011, ISCIII-Subdirección General de Evaluación y Fomento de la Investigación and the European Regional Development Fund. Una manera de hacer Europa). Support by the Centro de Investigación Biomédica en Red de Salud Mental, CIBERSAM (P82, 11INT3) and Generalitat de Catalunya (SGR20093) is also acknowledged. M. V. Puig was supported by the Japanese Society for the Promotion of Science (JSPS). Pau Celada is supported by the Researcher Stabilization Program of the Health Department of the Generalitat de Catalunya. We thank Dr. Allan Gulledge for permission to reproduce data in Figure 3.

glutamate release. Brain Res. 825, 161-171.

Amargós-Bosch, M., Bortolozzi, A., Puig, M. V., Serrats, J., Adell, A., Celada, P., et al. (2004). Coexpression and in vivo interaction of serotonin 1a and serotonin2a receptors in pyramidal neurons of prefrontal cortex. Cereb. Cortex 14, 281-299.

Andrade, R. (1998). Regulation of membrane excitability in the central nervous system by serotonin receptor subtypes. Ann. N.Y. Acad. Sci. 861, 190-203.
Andrade, R., Malenka, R. C., and Nicoll, R. A. (1986). A G protein couples serotonin and GABAB receptors to the same channel in hippocampus. Science 234, 1261-1265.

Andrade, R., and Nicoll, R. A. (1987). Pharmacologically distinct actions of serotonin on single pyramidal neurons of the rat hippocampus recorded in vitro. J. Physiol. 394, 99-124.

Araneda, R., and Andrade, R. (1991). 5-Hydroxytryptamine-2 and 5hydroxytryptamine-1A receptors 
mediate opposing responses on membrane excitability in rat association cortex. Neuroscience 40, 399-412.

Artigas, F. (2013). Serotonin receptors involved in antidepressant effects. Pharmacol. Ther. 137, 119-131.

Arvanov, V. L., Liang, X., Magro, P., Roberts, R., and Wang, R. Y. (1999). A pre- and postsynaptic modulatory action of 5-HT and the 5-HT2A/ 2C receptor agonist DOB on NMDAevoked responses in the rat medial prefrontal cortex. Eur. J. Neurosci. 11, 2917-2934.

Ashby, C. R. Jr., Edwards, E., Harkins, K., and Wang, R. Y. (1989a). Effects of $( \pm)$-DOI on medial prefrontal cortical cells: a microiontophoretic study. Brain Res. 498, 393-396.

Ashby, C. R., Edwards, E., Harkins, K., and Wang, R. Y. (1989b). Characterization of 5hydroxytryptamine 3 receptors in the medial prefrontal cortex: a microiontophoretic study. Eur. J. Pharmacol. 173, 193-196.

Ashby, C. R., Edwards, E., and Wang, R. Y. (1992). Action of serotonin in the medial prefrontal cortex: mediation by serotonin3-like receptors. Synapse 10, 7-15.

Ashby, C. R., Edwards, E., and Wang, R. Y. (1994). Electrophysiological evidence for a functional interaction between 5-HT(1A) and 5$\mathrm{HT}(2 \mathrm{~A})$ receptors in the rat medial prefrontal cortex: an iontophoretic study. Synapse 17, 173-181.

Ashby, C. R., Jiang, L. H., Kasser, R. J., and Wang, R. Y. (1990). Electrophysiological characterization of 5-hydroxytryptamine-2 receptors in the rat medial prefrontal cortex. J. Pharmacol. Exp. Ther. 252, 171-178.

Ashby, C. R. Jr., Minabe, Y., Edwards, E., and Wang, R. Y. (1991). 5HT3-like receptors in the rat medial prefrontal cortex: an electrophysiological study. Brain Res. 550, 181-191.

Avesar, D., and Gulledge, A. T. (2012). Selective serotonergic excitation of callosal projection neurons. Front. Neural Circuits 6:12. doi: 10.3389/fncir.2012.00012

Azmitia, E. C., Gannon, P. J., Kheck, N. M., and Whitaker-Azmitia, P. M. (1996). Cellular localization of the 5-HT1A receptor in primate brain neurons and glial cells. Neuropsychopharmacology 14, 35-46.

Barnes, N. M., and Sharp, T. (1999). A review of central 5HT receptors and their function. Neuropharmacology 38, 1083-1152.
Basar, E., and Güntekin, B. (2008). A review of brain oscillations in cognitive disorders and the role of neurotransmitters. Brain Res. 1235, 172-193.

Béique, J. C., Campbell, B., Perring, P., Hamblin, M. W., Walker, P., Mladenovic, L., et al. (2004). Serotonergic regulation of membrane potential in developing rat prefrontal cortex: coordinated expression of 5-hydroxytryptamine (5-HT)1A, 5-HT2A, and 5HT7 receptors. J. Neurosci. 24, 4807-4817.

Béique, J. C., Imad, M., Mladenovic, L., Gingrich, J. A., and Andrade, R. (2007). Mechanism of the 5-hydroxytryptamine $2 \mathrm{~A}$ receptormediated facilitation of synaptic activity in prefrontal cortex. Proc. Natl. Acad. Sci. U.S.A. 104, 9870-9875.

Benchenane, K., Tiesinga, P. H., and Battaglia, F. P. (2011). Oscillations in the prefrontal cortex: a gateway to memory and attention. Curr. Opin. Neurobiol. 21, 475-485.

Berendse, H. W., and Groenewegen, H. J. (1991). Restricted cortical termination fields of the midline and intralaminar thalamic nuclei in the rat. Neuroscience 42, 73-102.

Blier, P., and de Montigny, C. (1987). Modification of 5-HT neuron properties by sustained administration of the 5-HT1A agonist gepirone: electrophysiological studies in the rat brain. Synapse 1, 470-480.

Blue, M. E., Yagaloff, K. A., Mamounas, L. A., Hartig, P. R., and Molliver, M. E. (1988). Correspondence between 5-HT2 receptors and serotonergic axons in rat neocortex. Brain Res. 453, 315-328.

Bollimunta, A., Mo, J., Schroeder, C. E., and Ding, M. (2011). Neuronal mechanisms and attentional modulation of corticothalamic alpha oscillations. J. Neurosci. 31, 4935-4943.

Borsini, F., Giraldo, E., Monferini, E., Antonini, G., Parenti, M., Bietti, G., et al. (1995). BIMT 17, a 5-HT2A receptor antagonist and 5-HT1A receptor full agonist in rat cerebral cortex. Naunyn Schmiedebergs Arch. Pharmacol. 352, 276-282.

Bortolozzi, A., Díaz-Mataix, L., Scorza, M. C., Celada, P., and Artigas, F. (2005). The activation of 5HT receptors in prefrontal cortex enhances dopaminergic activity. J. Neurochem. 95, 1597-1607.

Boulougouris, V., Glennon, J. C., and Robbins, T. W. (2007). Dissociable effects of selective 5-HT2A and 5-HT2C receptor antagonists on serial spatial reversal learning in rats. Neuropsychopharmacology 33, 2007-2019.

Bruder, G. E., Sedoruk, J. P., Stewart, J. W., McGrath, P. J., Quitkin, F. M., and Tenke, C. E. (2008). Electroencephalographic alpha measures predict therapeutic response to a selective serotonin reuptake inhibitor antidepressant: pre- and post-treatment findings. Biol. Psychiatry 63, 1171-1177.

Burnet, P. W., Eastwood, S. L., Lacey, K., and Harrison, P. J. (1995). The distribution of 5-HT1A and 5-HT2A receptor mRNA in human brain. Brain Res. 676, 157-168.

Buschman, T. J., and Miller, E. K. (2007). Top-down versus bottomup control of attention in the prefrontal and posterior parietal cortices. Science 315, 1860-1862.

Cai, X., Gu, Z., Zhong, P., Ren, Y.,and Yan, Z. (2002a). Serotonin 5-HT1A receptors regulate AMPA receptor channels through inhibiting $\mathrm{Ca}^{2+} /$ calmodulin-dependent kinase II in prefrontal cortical pyramidal neurons. J. Biol. Chem. 277, 36553-36562.

Cai, X., Flores-Hernandez, J., Feng, J., and Yan, Z. (2002b). Activitydependent bidirectional regulation of GABAA receptor channels by the 5-HT4 receptormediated signaling in rat prefrontal cortical pyramidal neurons. $J$. Physiol. 540(Pt 3), 743-759.

Cardin, J. A., Carlen, M., Meletis, K., Knoblich, U., Zhang, F., Deisseroth, K., et al. (2009). Driving fast-spiking cells induces gamma rhythm and controls sensory responses. Nature 459, 663-667.

Carli, M., Baviera, M., Invernizzi, R. W., and Balducci, C. (2006). Dissociable contribution of 5-HT1A and 5$\mathrm{HT} 2 \mathrm{~A}$ receptors in the medial prefrontal cortex to different aspects of executive control such as impulsivity and compulsive perseveration in rats. Neuropsychopharmacology 31, 757-767.

Carr, D. B., and Sesack, S. R. (2000). Projections from the rat prefrontal cortex to the ventral tegmental area: target specificity in the synaptic associations with mesoaccumbens and mesocortical neurons. J. Neurosci. 20, 3864-3873.

Carr, G. V., and Lucki, I. (2011). The role of serotonin receptor subtypes in treating depression: a review of animal studies. Psychopharmacology (Berl.) 213, 265-287.

Carter, O. L., Burr, D. C., Pettigrew, J. D., Wallis, G. M., Hasler, F., and Vollenweider, F. X. (2005). Using psilocybin to investigate the relationship between attention, working memory, and the serotonin $1 \mathrm{~A}$ and 2A receptors. J. Cogn. Neurosci. 17, 1497-1508.

Casanovas, J. M., Berton, O., Celada, P., and Artigas, F. (2000). In vivo actions of the selective 5-HT1A receptor agonist BAY $\mathrm{x} 3702$ on serotonergic cell firing and release. Naunyn Schmiedebergs Arch. Pharmacol. 362, 248-254.

Celada, P., Puig, M. V., Casanovas, J. M., Guillazo, G., and Artigas, F. (2001). Control of dorsal raphe serotonergic neurons by the medial prefrontal cortex: involvement of serotonin-1A, GABA(A), and glutamate receptors. J. Neurosci. 21, 9917-9929.

Celada, P., Puig, M. V., Díaz-Mataix, L., and Artigas, F. (2008). The hallucinogen DOI reduces low-frequency oscillations in rat prefrontal cortex: reversal by antipsychotic drugs. Biol. Psychiatry 64, 392-400.

Chao, Y. P., Cho, K. H., Yeh, C. H., Chou, K. H., Chen, J. H., and Lin, C. P. (2009). Probabilistic topography of human corpus callosum using cytoarchitectural parcellation and high angular resolution diffusion imaging tractography. Hum. Brain Mapp. 30, 3172-3187.

Chaput, Y., and de Montigny, C. (1988). Effects of the 5-hydroxytryptamine receptor antagonist, BMY 7378, on 5- hydroxytryptamine neurotransmission: electrophysiological studies in the rat central nervous system. J. Pharmacol. Exp. Ther. 246, 359-370.

Cho, R. Y., Konecky, R. O., and Carter, C. S. (2006). Impairments in frontal cortical \{gamma\} synchrony and cognitive control in schizophrenia. Proc. Natl. Acad. Sci. U.S.A. 103, 19878-19883.

Clarke, H. F., Dalley, J. W., Crofts, H. S., Robbins, T. W., and Roberts, A. C. (2004). Cognitive inflexibility after prefrontal serotonin depletion. Science 304, 878-880.

Clarke, H. F., Walker, S. C., Crofts, H. S., Dalley, J. W., Robbins, T. W., and Roberts, A. C. (2005). Prefrontal serotonin depletion affects reversal learning but not attentional set shifting. J. Neurosci. 25, 532-538.

Clemett, D. A., Punhani, T., Duxon, M. S., Blackburn, T. P., and Fone, K. C. (2000). Immunohistochemical localisation of the 5-HT2C receptor protein in the rat CNS Neuropharmacology. 39, 123-132.

Compan, V., Segu, L., Buhot, M. C., and Daszuta, A. (1998). Selective increases in serotonin $5-\mathrm{HT} 1 \mathrm{~B} / 1 \mathrm{D}$ and $5-\mathrm{HT} 2 \mathrm{~A} / 2 \mathrm{C}$ binding sites in adult rat basal ganglia following 
lesions of serotonergic neurons. Brain Res. 793, 103-111.

Contreras, D., and Steriade, M. (1995). Cellular basis of EEG slow rhythms: a study of dynamic corticothalamic relationships. J. Neurosci. 15, 604-622.

Cruz, D. A., Eggan, S. M., Azmitia, E. C., and Lewis, D. A. (2004). Serotonin1A receptors at the axon initial segment of prefrontal pyramidal neurons in schizophrenia. Am. J. Psychiatry 161, 739-742.

Czyrak, A., Czepiel, K., Mackowiak, M., Chocyk, A., and Wedzony, K. (2003). Serotonin 5-HT1A receptors might control the output of cortical glutamatergic neurons in rat cingulate cortex. Brain Res. 989, 42-51.

Dalley, J. W., Theobald, D. E., Eagle, D. M., Passetti, F., and Robbins, T. W. (2002). Deficits in impulse control associated with tonically-elevated serotonergic function in rat prefrontal cortex. Neuropsychopharmacology 26 716-728.

Davies, M. F., Deisz, R. A., Prince, D. A., and Peroutka, S. J. (1987). Two distinct effects of 5-hydroxytryptamine on single cortical neurons. Brain Res. 423, 347-352.

De Felipe, J., Arellano, J. I., Gomez, A., Azmitia, E. C., and Muñoz, A. (2001). Pyramidal cell axons show a local specialization for GABA and 5HT inputs in monkey and human cerebral cortex. J. Comp. Neurol. $433,148-155$.

De Quervain, D. J., Henke, K., Aerni, A., Coluccia, D., Wollmer, M. A., Hock, C., et al. (2003). A functional genetic variation of the 5HT2A receptor affects human memory. Nat. Neurosci. 6, 1141-1142.

De Vry, J. (1995). 5-HT1A receptor agonists: recent developments and controversial issues. Psychopharmacology 121, 1-26.

Diaz-Mataix, L., Artigas, F., and Celada, P. (2006). Activation of pyramidal cells in rat medial prefrontal cortex projecting to ventral tegmental area by a 5-HT1A receptor agonist. Eur. Neuropsychopharmacol. 16, 288-296.

Diaz-Mataix, L., Scorza, M. C. Bortolozzi, A., Toth, M., Celada, P., and Artigas, F. (2005). Involvement of 5-HT1A receptors in prefrontal cortex in the modulation of dopaminergic activity: role in atypical antipsychotic action. J. Neurosci. 25, 10831-10843.

Edwards, E., Ashby, C. R., and Wang, R. Y. (1991). The effect of typical and atypical antipsychotic drugs on the stimulation of phosphoinositide hydrolysis produced by the 5-HT3 receptor agonist 2-methyl-serotonin. Brain Res. 545, 276-278.

Elvevåq, B., and Goldberg, T. (2000). Cognitive impairment in schizophrenia is the core of the disorder. Crit. Rev. Neurobiol. 14, $1-21$.

Erlander, M. G., Lovenberg, T. W., Baron, B. M., de Lecea, L. Danielson, P. E., Racke, M., et al. (1993). Two members of a distinct subfamily of 5-hydroxytryptamine receptors differentially expressed in rat brain. Proc. Natl. Acad. Sci. U.S.A. 90, 3452-3456.

Feng, J., Cai, X., Zhao, J., and Yan, Z. (2001). Serotonin receptors modulate GABAA receptor channels through activation of anchored protein kinase $\mathrm{C}$ in prefrontal cortical neurons. J. Neurosci. 22, 6502-6511.

Férézou, I., Cauli, B., Hill, E. L., Rossier, J., Hamel, E., and Lambolez, B. (2002). 5-HT3 receptors mediate serotonergic fast synaptic excitation of neocortical vasoactive intestinal peptide/cholecystokinin interneurons. J. Neurosci. 22, 7389-7397.

Fries, P. (2009). Neuronal gamma-band synchronization as a fundamental process in cortical computation. Annu. Rev. Neurosci. 32, 209-224.

Fries, P., Reynolds, J. H., Rorie, A. E., and Desimone, R. (2001). Modulation of oscillatory neuronal synchronization by selective visual attention. Science 291, 1560-1563.

Fumoto, M., Oshima, T., Kamiya, K., Kikuchi, H., Seki, Y., Nakatani, Y., et al. (2010). Ventral prefrontal cortex and serotonergic system activation during pedaling exercise induces negative mood improvement and increased alpha band in EEG. Behav. Brain Res. 213, 1-9.

Fuster, J. M. (1997). The Prefrontal Cortex, Anatomy, Physiology and Neuropsychology of the Frontal Lobe. Philadelphia, PA: Lippincott-Raven.

Gerard, C., el Mestikawy, S., Lebrand, C., Adrien, J., Ruat, M., Traiffort, E., et al. (1996). Quantitative RTPCR distribution of serotonin 5HT6 receptor mRNA in the central nervous system of control or 5, 7 dihydroxytryptamine-treated rats. Synapse. 23, 164-173.

Gerard, C., Martres, M. P., Lefevre, K., Miquel, M. C., Verge, D., Lanfumey, L., et al. (1997). Immuno-localization of serotonin 5-HT6 receptor-like material in the rat central nervous system. Brain Res. 746, 207-219.

Geyer, M. A., and Vollenweider, F. X. (2008). Serotonin research: contributions to understanding psychoses. Trends Pharmacol. Sci. 29, 445-453.

Gonzalez-Burgos, G., Hashimoto, T., and Lewis, D. A. (2010). Alterations of cortical GABA neurons and network oscillations in schizophrenia Curr. Psychiatry Rep. 12, 335-344.

Gonzalez-Burgos, G., and Lewis, D. A. (2008). GABA neurons and the mechanisms of network oscillations: implications for understanding cortical dysfunction in schizophrenia. Schizophr. Bull. 34, 944-961.

Gustafson, E. L., Durkin, M. M., Bard, J. A., Zgombick, J., and Branchek, T. A. (1996). A receptor autoradiographic and in situ hybridization analysis of the distribution of the 5-ht7 receptor in rat brain. Br. J. Pharmacol. 117, 657-666.

Hajós, M., Gartside, S. E., and Sharp, T. (1995). Inhibition of median and dorsal raphe neurones following administration of the selective serotonin reuptake inhibitor paroxetine. Naunyn Schmiedebergs Arch. Pharmacol. 351 , 624-629.

Hajós, M., Gartside, S. E., Varga, V., and Sharp, T. (2003). In vivo inhibition of neuronal activity in the rat ventromedial prefrontal cortex by midbrain-raphe nuclei: role of 5-HT1A receptors. Neuropharmacology 45, 72-81.

Hajos, M., Hajos-Korcsok, E., and Sharp, T. (1999). Role of the medial prefrontal cortex in 5-HT1A receptor-induced inhibition of 5-HT neuronal activity in the rat. Br. J. Pharmacol. 126, 1741-1750.

Hajós, M., Richards, C. D., Székely, A. D., and Sharp, T. (1998). An electrophysiological and neuroanatomical study of the medial prefrontal cortical projection to the midbrain raphe nuclei in the rat. Neuroscience 87, 95-108.

Hall, H., Farde, L., Halldin, C. Lundkvist, C., and Sedvall, G. (2000). Autoradiographic localization of $5-\mathrm{HT}(2 \mathrm{~A})$ receptors in the human brain using [3H]M100907 and [11C]M100907. Synapse 38, 421-431.

Harder, J. A., and Ridley, R. M. (2000). The 5-HT1A antagonis WAY 100635 alleviates cognitive impairments induced by dizocilpine (MK-801) in monkeys. Neuropharmacology 39, 547-552.

Harrison, A. A., Everitt, B. J., and Robbins, T. W. (1997). Central 5-HT depletion enhances impulsive responding without affecting the accuracy of attentional performance: interactions with dopaminergic mechanisms Psychopharmacology 133, 329-342.

Harvey, P., Bowie, C., and Friedman, J. (2001). Cognition in schizophrenia. Curr. Psychiatry Rep. 3, 423-428.

Higgins, G. A., and Kilpatrick, G. J. (1999). 5-HT(3) receptor antagonists. Expert Opin. Investig. Drugs 8, 2183-2188.

Hoffmann, R., Hendrickse, W., Rush, A. J., and Armitage, R. (2000). Slowwave activity during non-REM sleep in men with schizophrenia and major depressive disorders. Psychiatry Res. 95, 215-225.

Innis, R. B., and Aghajanian, G. K. (1987). Pertussis toxin blocks 5-HT1A and GABAB receptormediated inhibition of serotonergic neurons. Eur. J. Pharmacol. 143, 195-204.

Jacobs, B. L., and Azmitia, E. C. (1992). Structure and function of the brain serotonin system. Physiol. Rev. 72, 165-229.

Jakab, R. L., and Goldman-Rakic, P. S. (1998). 5-Hydroxytryptamine(2A) serotonin receptors in the primate cerebral cortex: possible site of action of hallucinogenic and antipsychotic drugs in pyramidal cell apical dendrites. Proc. Natl. Acad. Sci. U.S.A. 95, 735-740.

Jakab, R. L., and Goldman-Rakic, P. S. (2000). Segregation of serotonin 5-HT2A and 5-HT3 receptors in inhibitory circuits of the primate cerebral cortex. J. Comp. Neurol. 417, 337-348.

Jankowski, M. P., and Sesack, S. R. (2002). Electron microscopic analysis of the GABA projection from the dorsal raphe nucleus to the prefrontal cortex in the rat. Soc. Neurosci. Abstr. 587.8.

Jansson, A., Tinner, B., Bancila, M., Verge, D., Steinbusch, H. W., Agnati, L. F., et al. (2001). Relationships of 5-hydroxytryptamine immunoreactive terminal-like varicosities to 5-hydroxytryptamine-2A receptorimmunoreactive neuronal processes in the rat forebrain. J. Chem. Neuroanat. 22, 185-203.

Jensen, O., Gelfand, J., Kounios, J., and Lisman, J. E. (2002). Oscillations in the alpha band $(9-12 \mathrm{~Hz})$ increase with memory load during retention in a short-term memory task. Cereb. Cortex 12, 877-882.

Kargieman, L., Riga, M. S., Artigas, F. and Celada, P. (2012). Clozapine reverses phencyclidine-induced desynchronization of prefrontal cortex through a 5-HT1A receptor-dependent mechanism. Neuropsychopharmacology 37, 723-733. 
Kargieman, L., Santana, N., Mengod, G., Celada, P., and Artigas, F. (2007). Antipsychotic drugs reverse the disruption in prefrontal cortex function produced by NMDA receptor blockade with phencyclidine. Proc. Natl. Acad. Sci. U.S.A. 104, 14843-14848.

Keshavan, M. S., Reynolds, C. F. 3rd., Miewald, J. M., Montrose, D. M., Sweeney, J. A., Vasko, R. C. Jr., et al. (1998). Delta sleep deficits in schizophrenia: evidence from automated analyses of seep data. Arch. Gen. Psychiatry 55, 443-448.

Kia, H. K., Brisorgueil, M. J., Hamon, M., Calas, A., and Vergé, D. (1996). Ultrastructural localization of 5-hydroxytryptamine(1A) receptors in the rat brain. J. Neurosci. Res. 46, 697-708.

Krnjevic, K., and Phillis, J. W. (1963). Iontophoretic studies of neurones in the mammalian cerebral cortex. J. Physiol. 165, 274-304.

Lambe, E. K., and Aghajanian, G. K. (2004). Serotonin (5-HT) Supresses Electrophysiological Effects by Hallucinogens in Rat Prefrontal Cortex. Program No. 394.3. Abstract Viewer/Intinerary Planner. Washington, DC: Society for Neuroscience.

Landsness, E. C., Crupi, D., Hulse, B. K., Peterson, M. J., Huber, R., Ansari, H., et al. (2009). Sleepdependent improvement in visuomotor learning: a causal role for slow waves. Sleep 32, 1273-1284.

Liu, S., Bubar, M. J., Hillman, G. R., and Cunningham, K. A. (2007). Serotonin2C Receptor (5-HT2CR) Localization in GABA neurons of the rat medial prefrontal cortex: implications for understanding the neurobiology of addiction. Neuroscience 146, 1677-1688.

Lladó-Pelfort, L., Assié, M. B., Newman-Tancredi, A., Artigas, F., and Celada, P. (2010). Preferential in vivo action of F15599, a novel 5-HT1A receptor agonist, at postsynaptic 5-HT1A receptors. $\mathrm{Br}$. J. Pharmacol. 160, 1929-1940.

Lladó-Pelfort, L., Assié, M. B., Newman-Tancredi, A., Artigas, F., and Celada, P. (2012a). In vivo electrophysiological and neurochemical effects of the selective 5-HT1A receptor agonist, F13640, at preand postsynaptic 5-HT1A receptors in the rat. Psychopharmacology (Berl.) 221, 261-272.

Lladó-Pelfort, L., Santana, N., Ghisi, V., Artigas, F., and Celada, P. (2012b). 5-HT1A receptor agonists enhance pyramidal cell firing in prefrontal cortex through a preferential action on GABA interneurons. Cereb. Cortex 22, 1487-1497.

López-Giménez, J. F., Vilaró, M. T., Palacios, J. M., and Mengod, G. (1998). [3H] MDL100, 907 labels 5-HT2A serotonin receptors selectively in primate brain. Neuropharmacology 37, 1147-1158.

Lucas, G., Compan, V., Charnay, Y., Neve, R. L., Nestler, E. J., Bockaert, J., et al. (2005). Frontocortical 5-HT4 receptors exert positive feedback on serotonergic activity: viral transfections, subacute and chronic treatments with 5HT4 agonists. Biol. Psychiatry 57, 918-925.

Lucas, G., Rymar, V. V., Du, J., MnieFilali, O., Bisgaard, C., Manta, S., et al. (2007). Serotonin(4) (5HT(4)) receptor agonists are putative antidepressants with a rapid onset of action. Neuron 55, 712-725.

Ma, L., Shalinsky, M. H., Alonso, A., and Dickson, C. T. (2007). Effects of serotonin on the intrinsic membrane properties of layer II medial entorhinal cortex neurons. Hippocampus 17, 114-129.

Marshall, L., Helgadóttir, H., Mölle, M., and Born, J. (2006). Boosting slow oscillations during sleep potentiates memory. Nature 444, 610-613.

Martin, P., Beninger, R. J., Hamon, M., and Puech, A. J. (1990). Antidepressant-like action of 8OH-DPAT, a 5-HT1A agonist, in the learned helplessness paradigm: evidence for a postsynaptic mechanism. Behav. Brain Res. 38, 135-144.

Martin-Cora, F. J., and Pazos, A. (2004). Autoradiographic distribution of 5-HT7 receptors in the human brain using $[3 \mathrm{H}]$ mesulergine: comparison to other mammalian species. Br. J. Pharmacol. 141, 92-104.

Martinez, D., Hwang, D. R., Mawlawi, O., Slifstein, M., Kent, J., Simpson, N., et al. (2001). Differential occupancy of somatodendritic and postsynaptic $5 \mathrm{HT}(1 \mathrm{~A})$ receptors by pindolol: a dose-occupancy study with [C- 11]WAY 100635 and positron emission tomography in humans. Neuropsychopharmacology 24, 209-229.

Martín-Ruiz, R., Puig, M. V., Celada, P., Shapiro, D. A., Roth, B. L., Mengod, G., et al. (2001). Control of serotonergic function in medial prefrontal cortex by serotonin-2A receptors through a glutamatedependent mechanism. J. Neurosci. 21, 9856-9866.

Massi, L., Lagler, M., Hartwich, K., Borhegyi, Z., Somogyi, P., and
Klausberger, T. (2012). Temporal dynamics of parvalbuminexpressing axo-axonic and basket cells in the rat medial prefrontal cortex in vivo. J. Neurosci. 32, 16496-16502.

Mello e Souza, T., Rodrigues, C., Souza, M. M., Vinade, E., Coitinho, A., Choi, H., et al. (2001). Involvement of the serotonergic type 1A (5HT1A) receptor in the agranular insular cortex in the consolidation of memory for inhibitory avoidance in rats. Behav. Pharmacol. 12, 349-353.

Miner, L. A. H., Backstrom, J. R., Sanders-Bush, E., and Sesack, S. R. (2003). Ultrastructural localization of serotonin-2A receptors in the middle layers of the rat prelimbic prefrontal cortex. Neuroscience 116, 107-117.

Misane, I., and Ögren, S. O. (2003). Selective 5-HT1A antagonists WAY 100635 and NAD-299 attenuate the impairment of passive avoidance caused by scopolamine in the rat. Neuropsychopharmacology 28, 253-264.

Morales, M., and Bloom, F. E. (1997). The 5-HT3 receptor is present in different subpopulations of GABAergic neurons in the rat telencephalon. J. Neurosci. 17, 3157-3167.

Mukovski, M., Chauvette, S., Timofeev, I., and Volgushev, M. (2007). Detection of active and silent states in neocortical neurons from the field potential signal during slow-wave sleep. Cereb. Cortex 17, 400-414.

Newberry, N. R., Footitt, D. R. Papanastassiou, V., and Reynolds, D. J. (1999). Actions of 5-HT on human neocortical neurones in vitro. Brain Res. 833, 93-100.

Offord, S. J., Ordway, G. A., and Frazer, A. (1988). Application of (125I)iodocyanopindolol to measure 5-hydroxytryptamine1B receptors in the brain of the rat J. Pharmacol. Exp. Ther. 244, 144-153.

Pandey, G. N., Dwivedi, Y., Ren, X., Rizavi, H. S., Faludi, G., Sarosi, A., et al. (2006). Regional distribution and relative abundance of serotonin $(2 \mathrm{c})$ receptors in human brain: effect of suicide. Neurochem. Res. 31, 167-176.

Pazos, A., Cortés, R., and Palacios, J. M. (1985). Quantitative autoradiographic mapping of serotonin receptors in the rat brain. II. Serotonin-2 receptors. Brain Res. 346, 231-249.

Pazos, A., and Palacios, J. M. (1985). Quantitative autoradiographic mapping of serotonin receptors in the rat brain. I. Serotonin-1 receptors. Brain Res. 346, 205-230.

Pompeiano, M., Palacios, J. M., and Mengod, G. (1992). Distribution and cellular localization of mRNA coding for 5-HT1A receptor in the rat brain: correlation with receptor binding. J. Neurosci. 12 440-453.

Pompeiano, M., Palacios, J. M., and Mengod, G. (1994). Distribution of the serotonin 5-HT2 receptor family mRNAs: comparison between 5 HT2A and 5-HT2C receptors. Mol. Brain Res. 23, 163-178.

Puig, M. V., Artigas, F., and Celada, P. (2005). Modulation of the activity of pyramidal neurons in rat prefrontal cortex by raphe stimulation in vivo: involvement of serotonin and GABA. Cereb. Cortex 15, $1-14$.

Puig, M. V., Celada, P., Díaz-Mataix, L., and Artigas, F. (2003). In vivo modulation of the activity of pyramidal neurons in the rat medial prefrontal cortex by 5-HT2A receptors. Relationship to thalamocortical afferents. Cereb. Cortex 13, 1870-1882.

Puig, M. V., and Gulledge, A. (2011). Serotonin and prefrontal cortex function: neurons, networks, and circuits. Mol. Neurobiol. 44, 449-464.

Puig, M. V., and Miller, E. K. (2012). The role of prefrontal dopamine D1 receptors in the neural mechanisms of associative learning. Neuron 74, 874-886.

Puig, M. V., Santana, N., Celada, P., Mengod, G., and Artigas, F. (2004). In vivo excitation of GABA interneurons in the medial prefrontal cortex through 5HT3 receptors. Cereb. Cortex 14, 1365-1375.

Puig, M. V., Watakabe, A., Ushimaru, M., Yamamori, T., and Kawaguchi, Y. (2010). Serotonin modulates fast-spiking interneuron and synchronous activity in the rat prefrontal cortex through 5-HT1A and 5-HT2A receptors. J. Neurosci. 30, 2211-2222.

Reader, T. A., Ferron, A., Descarries, L., and Jasper, H. H. (1979). Modulatory role for biogenic amines in the cerebral cortex. Microiontophoretic studies. Brain Res. 160, 217-229.

Riad, M., Garcia, S., Watkins, K. C., Jodoin, N., Doucet, E., Langlois, X., et al. (2000). Somatodendritic localization of 5-HT1A and preterminal axonal localization of 5-HT1B serotonin receptors in adult rat brain. J. Comp. Neurol. 417, 181-194. 
Robbins, T. W., and Arnsten, A. F. (2009). The neuropsychopharmacology of fronto-executive function: monoaminergic modulation. Аnпи. Rev. Neurosci. 32, 267-287.

Roberts, M. H., and Straughan, D. W. (1967). Excitation and depression of cortical neurones by 5 hydroxytryptamine. J. Physiol. 193, 269-294.

Roth, B. L., Hanizavarek, S. M., and Blum, A. E. (2004). Serotonin receptors represent highly favourable molecular targets for cognitive enhancement in schizophrenia and other disorders. Psychopharmacology 174, 17-24.

Sanchez-Vives, M. V., and McCormick, D. A. (2000). Cellular and network mechanisms of rhythmic recurrent activity in neocortex. Nat. Neurosci. $3,1027-1034$

Santana, N., Bortolozzi, A., Serrats, J., Mengod, G., and Artigas, F. (2004). Expression of serotonin $1 \mathrm{~A}$ and serotonin2A receptors in pyramidal and GABAergic neurons of the rat prefrontal cortex. Cereb. Cortex 14, 1100-1109.

Sari, Y. (2004). Serotonin(1B) receptors: from protein to physiological function and behavior. Neurosci. Biobehav. Rev. 28, 565-582.

Scholes, K. E., Harrison, B. J., O'Neill, B. V., Leung, S., Croft, R. J., Pipingas, A., et al. (2006). Acute serotonin and dopamine depletion improves attentional control: findings from the Stroop task. Neuropsychopharmacology 32, 1600-1610.

Sheldon, P. W., and Aghajanian, G. K. (1991). Excitatory responses to serotonin $(5-\mathrm{HT})$ in neurons of the rat piriform cortex: evidence for mediation by 5 -HT1C receptors in pyramidal cells and 5-HT2 receptors in interneurons. Synapse 9, 208-218.

Siegel, M., Warden, M. R., and Miller, E. K. (2009). Phase-dependent neuronal coding of objects in shortterm memory. Proc. Natl. Acad. Sci. U.S.A. 106, 21341-21346.

Sirota, P., Mosheva, T., Shabtay, H., Giladi, N., and Korczyn, A. D. (2000). Use of the selective serotonin 3 receptor antagonist ondansetron in the treatment of neuroleptic-induced tardive dyskinesia. Am. J. Psychiatry 157, 287-289.

Smythies, J. (2005). Section, V. Serotonin system. Int. Rev. Neurobiol. 64, 217-268.

Sohal, V. S., Zhang, F., Yizhar, O., and Deisseroth, K. (2009). Parvalbumin neurons and gamma rhythms enhance cortical circuit performance. Nature 459, 698-702.
Spencer, K. M., Nestor, P. G., Niznikiewicz, M. A., Salisbury, D. F., Shenton, M. E., and McCarley, R. W. (2003). Abnormal neural synchrony in schizophrenia. J. Neurosci. 23, 7407-7411.

Sprouse, J. S., and Aghajanian, G. K. (1987). Electrophysiological responses of serotonergic dorsal raphe neurons to 5-HT1A and 5-HT1B agonists. Synapse 1, 3-9.

Staubli, U., and Xu, F. B. (1995). Effects of 5-HT3 receptor antagonism on hippocampal theta rhythm, memory, and LTP induction in the freely moving rat. J. Neurosci. 15, 2445-2452.

Steriade, M. (2006). Grouping of brain rhythms in corticothalamic systems. Neuroscience 137, 1087-1106.

Steriade, M., Contreras, D., Amzica, F., and Timofeev, I. (1996). Synchronization of fast (30$40 \mathrm{~Hz}$ ) spontaneous oscillations in intrathalamic and thalamocortical networks. J. Neurosci. 16, 2788-2808.

Steriade, M., Nuñez, A., and Amzica, F. (1993). A novel slow $(<1 \mathrm{~Hz})$ oscillation of neocortical neurons in vivo: depolarizing and hyperpolarizing components. J. Neurosci. 13, 3252-3265.

Steriade, M., Timofeev, I., and Grenier, F. (2001). Natural waking and sleep states: a view from inside neocortical neurons. J. Neurophysiol. 85, 1969-1985.

Stickgold, R. (2005). Sleep-dependent memory consolidation. Nature 437, 1272-1278.

Tada, K., Kasamo, K., Ueda, N. Suzuki, T., Kojima, T., and Ishikawa, K. (1999). Anxiolytic 5-Hydroxytryptamine1A agonists suppress firing activity of dorsal hippocampus CA1 pyramidal neurons through a postsynaptic mechanism: single-unit study in unanesthetized, unrestrained rats. J. Pharmacol. Exp. Ther. 288, 843-848.

Talpos, J. C., Wilkinson, L. S., and Robbins, T. W. (2006). A comparison of multiple 5-HT receptors in two tasks measuring impulsivity. J. Psychopharmacol. 20, 47-58.

Tanaka, E., and North, R. A. (1993). Actions of 5 hydroxytryptamine on neurons of the rat cingulate cortex. J. Neurophysiol. 69, 1749-1757.

Tassone, A., Madeo, G., Schirinzi, T., Vita, D., Puglisi, F., Ponterio, G., et al. (2011). Activation of 5-HT6 receptors inhibits corticostriatal glutamatergic transmission. Neuropharmacology 61, 632-637.

Thierry, A. M., Chevalier, G., Ferron, A., and Glowinski, J. (1983).
Diencephalic and mesencephalic efferents of the medial prefrontal cortex in the rat: electrophysiological evidence for the existence of branched axons. Exp. Brain Res. 50, 275-282.

Thierry, A. M., Deniau, J. M., and Feger, J. (1979). Effects of stimulation of the frontal cortex on identified output VMT cells in the rat. Neurosci. Lett. 15, 103-107.

Tong, Z. Y., Overton, P. G., and Clark, D. (1996). Stimulation of the prefrontal cortex in the rat induces patterns of activity in midbrain dopaminergic neurons which resemble natural burst events. Synapse 22, 195-208.

Uhlhaas, P. J., and Singer, W. (2006). Neural synchrony in brain disorders: relevance for cognitive dysfunctions and pathophysiology. Neuron 52, 155-168.

Upton, N., Chuang, T. T., Hunter, A. J., and Virley, D. J. (2008). 5-HT6 receptor antagonists as novel cognitive enhancing agents for Alzeimer's disease. Neurotherapeutics 5 458-469.

Vázquez-Borsetti, P., Celada, P., Cortés, R., and Artigas, F. (2011) Simultaneous projections from prefrontal cortex to dopaminergic and serotonergic nuclei. Int. J. Neuropsychopharmacol. 14, 289-302.

Vázquez-Borsetti, P., Cortés, R., and Artigas, F. (2009). Pyramidal neurons in rat prefrontal cortex projecting to ventral tegmental area and dorsal raphe nucleus express 5 HT2A receptors. Cereb. Cortex 19, 1678-1686.

Vilaró, M. T., Cortes, R., Gerald, C., Branchek, T. A., Palacios, J. M., and Mengod, G. (1996). Localization of 5-HT4 receptor mRNA in rat brain by in situ hybridization histochemistry. Brain Res. Mol. Brain Res. 43, 356-360.

Vilaró, M. T., Cortés, R., and Mengod, G. (2005). Serotonin 5-HT4 receptors and their mPRNAs in rat and guinea pig brain: distribution and effect of neurotoxic lesions. J. Comp. Neurol. 484, 418-439.

Villalobos, C., Beique, J. C., Gingrich, J. A., and Andrade, R. (2005). Serotonergic regulation of calciumactivated potassium currents in rodent prefrontal cortex. Eur. J. Neurosci. 22, 1120-1126.

Waeber, C., Sebben, M., Nieoullon, A., Bockaert, J., and Dumuis, A (1994). Regional distribution and ontogeny of 5-HT4 binding sites in rodent brain. Neuropharmacology $33,527-541$.
Ward, L. M. (2003). Synchronous neural oscillations and cognitive processes. Trends Cogn. Sci. 7, 553-559.

Watling, K. J., Beer, M. S., and Stanton, J. A. (1989). Effects of clozapine and other neuroleptics on binding of [3H]-Q ICS 205-930 to central 5-HT3 recognition sites. Br. J. Pharmacol. 98(Suppl.), 813P.

Weber, E., and Andrade, R. (2010). Htr2a gene and 5-HT2A receptor expression in the cerebral cortex studied using genetically modified mice. Front. Neurosci. 4:36. doi: 10.3389/fnins.2010. 00036

Williams, G. V., and Goldman-Rakic, P. S. (1995). Modulation of memory fields by dopamine D1 receptors in prefrontal cortex. Nature 376, 572-575.

Williams, G. V., Rao, S. G., and Goldman-Rakic, P. S. (2002). The physiological role of 5-HT2A receptors in working memory. J. Neurosci. 22, 2843-2854.

Williams, J. T., Colmers, W. F., and Pan, Z. Z. (1988). Voltage- and Ligand-Activated inwardly rectifying currents in dorsal raphe neurons in vivo. J. Neurosci. 8, 3499-3506.

Willins, D. L., Deutch, A. Y., and Roth, B. L. (1997). Serotonin 5-HT2A receptors are expressed on pyramidal cells and interneurons in the rat cortex. Synapse 27, 79-82.

Winstanley, C. A., Chudasama, Y., Dalley, J. W., Theobald, D. E. H., Glennon, J. C., and Robbins, T. W. (2003). Intra-prefrontal 8OH-DPAT and M100907 improve visuospatial attention and decrease impulsivity on the five-choice serial reaction time task in rats. Psychopharmacology 167, 304-314.

Winstanley, C. A., Theobald, D. E. H., Dalley, J. W., Glennon, J. C., and Robbins, T. W. (2004). 5HT2A and 5-HT2C receptor antagonists have opposing effects on a measure of impulsivity: interactions with global 5-HT depletion. Psychopharmacology 176, 376-385.

Woolley, M. L., Marsden, C. A., and Fone, K. C. (2004). 5-ht6 receptors. Curr. Drug Targets CNS Neurol. Disord. 3, 59-79.

Xiang, Z., and Prince, D. A. (2003). Heterogeneous actions of serotonin on interneurons in rat visual cortex. J. Neurophysiol. 89, 1278-1287.

Yan, Z. (2002). Regulation of GABAergic inhibition by serotonin signaling in prefrontal cortex: molecular mechanisms and functional implications. Mol. Neurobiol. 26, 203-216.

Yu, X., Fumoto, M., Nakatani, Y., Sekiyama, T., Kikuchi, H., Seki, Y., et al. (2011). Activation of 
the anterior prefrontal cortex and serotonergic system is associated with improvements in mood and EEG changes induced by Zen meditation practice in novices. Int. J. Psychophysiol. 80, 103-111.

Yuen, E. Y., Jiang, Q., Chen, P., Feng, J., and Yan, Z. (2008). Activation of 5-HT2A/C receptors counteracts 5-HT1A regulation of n-methyl-D-aspartate receptor channels in pyramidal neurons of prefrontal cortex. J. Biol. Chem. 283, 17194-17220.

Zahorodna, A., Bobula, B., Grzegorzewska, M., Tokarski, K., and Hess, G. (2004). The influence of repeated administration of clozapine and haloperidol on the effects of the activation of 5-HT(1A), 5-HT(2) and 5HT(4) receptors in rat frontal cortex. J. Physiol. Pharmacol. 55, 371-379.

Zhang, J. Y., Ashby, C. R., and Wang, R. Y. (1994). Effect of pertussis toxin on the response of rat medial prefrontal cortex cells to the iontophoresis of serotonin receptor agonists. J. Neural Transm. Gen. Sect. 95, 165-172.

Zhang, Z. W. (2003). Serotonin induces tonic firing in layer $\mathrm{V}$ pyramidal neurons of rat prefrontal cortex during postnatal development. Neuroscience 23, 3373-3384.
Zhong, P., Yuen, E. Y., and Yan, Z. (2008). Modulation of neuronal excitability by serotonin-NMDA interactions in prefrontal cortex. Mol. Cell. Neurosci. 38 290-299.

Zhou, F. M., and Hablitz, J. J. (1999). Activation of serotonin receptors modulates synaptic transmission in rat cerebral cortex. J. Neurophysiol. 82, 2989-2999.

Conflict of Interest Statement: The authors declare that the research was conducted in the absence of any commercial or financial relationships that could be construed as a potential conflict of interest.
Received: 31 January 2013; paper pending published: 07 March 2013; accepted: 01 April 2013; published online: 19 April 2013.

Citation: Celada P, Puig MV and Artigas F (2013) Serotonin modulation of cortical neurons and networks. Front. Integr. Neurosci. 7:25. doi: 10.3389/fnint. 2013.00025

Copyright (c) 2013 Celada, Puig and Artigas. This is an open-access article distributed under the terms of the Creative Commons Attribution License, which permits use, distribution and reproduction in other forums, provided the original authors and source are credited and subject to any copyright notices concerning any third-party graphics etc. 